Article

\title{
An AHP-SWOT-Fuzzy TOPSIS Approach for Achieving a Cross-Border RES Cooperation
}

\author{
Aikaterini Papapostolou 1 , Charikleia Karakosta*(D), Georgios Apostolidis and Haris Doukas \\ Energy Policy Unit (EPU-NTUA), Decision Support Systems Laboratory, School of Electrical and Computer \\ Engineering, National Technical University of Athens, 15780 Athens, Greece; kpapap@epu.ntua.gr (A.P.); \\ george_apo_8@hotmail.com (G.A.); h_doukas@epu.ntua.gr (H.D.) \\ * Correspondence: chkara@epu.ntua.gr; Tel.: +30-210-772-2083
}

Received: 28 January 2020; Accepted: 2 April 2020; Published: 4 April 2020

\begin{abstract}
The emerging need to tackle climate change and mitigate greenhouse gas emissions has led to the consolidation of interest in renewable energy sources (RES) setting specific targets in the European area. To achieve the ambitious targets set, Member States are given the opportunity to cooperate with one or more of their developing neighboring countries. The aim of this paper is to develop a methodological framework based on the combination of the Strengths, Weaknesses, Opportunities and Threats (SWOT) analysis with the Analytic Hierarchy Process (AHP) and the Fuzzy Technique for Order of Preference by Similarity to Ideal Solution (Fuzzy TOPSIS) methods for adopting the most appropriate strategic plan, in order to establish a successful energy cooperation that will create beneficial conditions for all the involved parties. The results could be important in facilitating decision makers to assess the role and design of this cooperation mechanism. Key insights will also emerge with regards to opportunities for energy strategy cooperation between Europe and its neighboring countries.
\end{abstract}

Keywords: renewable energy sources; energy policy; SWOT analysis; multi-criteria analysis; AHP; fuzzy TOPSIS; Morocco; Egypt

\section{Introduction}

\subsection{Background and Motivation}

Nowadays, there is plenty of scientific evidence to prove that climate is changing due to the increasing quantities of greenhouse gas (GHG) emissions, for which human activity is mainly responsible [1]. It is also a fact that as the years go by, global energy demand is rising dramatically, which is the main cause of the bulk of these emissions, as more and more fossil fuels are burnt in order to meet those demands. In order to tackle climate change, the European Commission (EC) has already adopted a series of measures to facilitate the clean energy transition in its energy sector in the future. Recently, the EC Clean Energy for all Europeans package entered into force including policies and legislation regarding renewable energy sources (RES), energy efficiency and GHG emissions reduction, while the recast Renewable Energy Directive (RED) [2,3] envisages an ambitious, binding target of $32 \%$ for RES in the European Union (EU) energy mix by 2030.

It is worth mentioning also that the international regulatory framework, as well as the international initiatives, call for increased cooperation, as a crucial factor to fully exploit the vast RES potential worldwide. This will constitute a win-win situation as it will allow us to meet climate change objectives in a cost-effective way and enable countries to develop their economies in a more sustainable way. In addition, it will allow the development of a competitive industry in the field of low-carbon technologies [4]. 
To meet the ambitious energy targets set, Member States are given the opportunity to cooperate with one or more of the neighboring countries towards this direction. More specifically, one or more Member States may cooperate with one or more developing neighboring countries on joint projects within the territory of the latter, with regard to electricity generation from RES. Any amount of electricity generated by such installations may be taken into account for the purposes of measuring compliance with the Member States' national overall targets, if certain demanding conditions are met.

As Karakosta et al. (2013) [5] noted and compared to the other cooperation mechanisms envisaged by the EU legislation, barriers to the implementation of the cooperation mechanism on joint projects between EU and developing countries include poor grid infrastructure (in order for the energy to be transferred into the community), geopolitical unrest, risks of limited public acceptance, existing legal limitations and complex financing schemes.

However, and despite the potential difficulties that lie in the implementation of the mechanism, especially considering that any such project should be able to attract private funding, there are major benefits as well [6]. In addition, joint projects with developing countries, although quite complex considering the involved parties, different country contexts, regulations, infrastructures etc., could be a crucial instrument striving towards international RES cooperation to foster the social, economic and environmental benefits of RES electricity (RES-E) projects.

\subsection{Contributions}

The core objective of this paper is to assess, through case studies and integrated analysis to what extent cooperation with developing neighboring countries can help Europe achieve its RES targets and beyond this, trigger the deployment of RES-E projects in the host countries and create synergies and mutually beneficial circumstances for all involved parties [7]. In order to support the development of cooperation mechanisms and implement a successful collaboration, the current and future situation of the host country need to be examined, so as to be able to develop the most appropriate energy policies [8]. This could be achieved through the analysis of Strengths, Weaknesses, Opportunities and Threats (SWOT) of the country under examination.

SWOT analysis is used in order to assess a host country's present situation as conducive to implement RES projects under the cross-border cooperation framework. The aim is to identify factors that are favorable (Strengths, Opportunities) and unfavorable (Weaknesses, Threats) to the development of this cross-border cooperation. The SWOT analysis intents to identify win-win actions for both EU Member States and neighboring countries by providing answers to the following questions [9]:

- How can we exploit the most from the regions' strengths to increase the cumulative welfare of both EU and the regional countries?

- How can we circumvent the regions' weaknesses by choosing the best technology options?

- How can we create opportunities and then capitalize on them?

- How can we manage possible threats, so that the RES targets will not be compromised by unfavorable evolution?

However, SWOT analysis cannot be considered as a sufficient stand-alone tool to solve this energy planning problem. The complex nature of this process requires the use of multi-criteria decision making (MCDM) methods, which seem to be extremely powerful tools and able to deal with the different aspects that these problems include $[8,10,11]$. MCDM methods have been applied to many energy-related problems, such as energy planning and selection, energy resource allocation, energy policy, management of building energy, transportation systems, and electric utility planning [6,12-15]. Such problems have been discussed either from the perspective of a single criterion decision problem, such as maximizing profit or minimizing cost, or in relation to complex multi-criteria decision problems [16]. According to Wang et al. 2009 [17], the most frequently used criteria are investment cost, $\mathrm{CO}_{2}$ emissions, efficiency, operation and maintenance cost, land use, fuel cost, and job creation. 
For this study, Analytic Hierarchy Process (AHP) is utilized in order to determine the weights of the criteria that will be then used to assess the alternative proposed strategies to be followed towards a successful implementation of cooperation mechanisms. After the criteria weights calculation, the Fuzzy Technique for Order of Preference by Similarity to Ideal Solution (Fuzzy TOPSIS) method is used, in order to rank the proposed strategies that emerge towards the promotion of cross border cooperation, since it is widely used to solve decision making problems.

In the current study, the perspectives of a cross-border energy cooperation between the EU and Morocco, which was selected as a potential host country, are examined. The reason why this country was selected has to do with the fact that the development of such a cooperation seems extremely feasible. First of all, Morocco is Spain's southern border and only a relatively narrow body of water separates the two countries. This is a favorable factor for this direction, considering that this kind of cooperation requires electrical interconnection between the countries. It is also worth mentioning that Morocco is the only North African country that has an interconnection with a European country. More specifically, a submarine cable connecting the country with Spain already exists, which is both important for importing energy and also for potential energy exports in the following years. Moreover, the country has strong potential in developing RES, while an upward trend in the energy demand in the past several years can be observed [18].

Finally, the results of the pilot application in Morocco were compared with the results of an additional case study. This paper also provides a comparative analysis between Morocco and Egypt, so as to obtain a clearer picture of the pros and cons of the applied methodology.

\subsection{Decision Support Methods Review}

\subsubsection{SWOTAnalysis}

SWOT analysis is a well-known analytical tool, which has been widely applied for strategic decision-making processes [19], in regional energy planning and management [20,21], as well as in renewable energy schemes [22,23]. In particular, SWOT analysis has been used so far in order to investigate and assess the current status of RES in different regions [23,24] yielding a good basis for formulating policy recommendations regarding enhanced utilization of RES. The use of SWOT analysis for exploring energy sector conditions and developing an environmental strategic plan could enable a correct comprehension of the current energy situation and serve as a basis for objectives and strategy proposals [25]. Lei et al. 2019 [26] exploit through the SWOT analysis a new opportunity for African countries to develop their solar power resource through mutually beneficial cooperation between Africa and China within the framework of the Belt and Road Initiative (BRI). Agyekum et al. 2020 [27] used the SWOT analysis to assess Ghana's nuclear power program. The research found out that in Ghana there are a lot of strengths and opportunities in investing in nuclear. However, issues such as a porous security system, corruption, porous borders and policy discontinuity are threats to the smooth implementation and operation of a nuclear power plant.

Kamran et al. 2020 [28] performed a SWOT analysis as a reference point that diagnoses the feasibility of current status and future roadmap to nurture the renewable energy sector in Pakistan. Igliński et al. 2016 [29] examined the history, current state and prospects for the development of the wind power sector in Poland including a SWOT analysis of wind power investment. Studies also exist in the literature that combine the SWOT analysis with MCDM methods. Ervural et al. 2018 [30] used a combined Analytic Network Process (ANP) and fuzzy TOPSIS method with SWOT analysis in order to evaluate Turkey's energy planning strategies. The results showed that the most important priority was to turn the country into an energy terminal by effectively using the geo-strategic position within the framework of the regional cooperation. Wang et al. 2020 [31] integrated the fuzzy AHP and SWOT model for choosing and assessing the strategic renewable energy technologies in Pakistan by considering four indicators and 17 sub-indicators. The finding of that study demonstrated that socio-political and economic criteria were the influential indicators for the selection of renewable 
energy sources. Khan 2018 [32] evaluated the prioritized the strategies for stimulating the growth of the Iranian Compressed Natural Gas (CNG) market through the application of SWOT analysis along with a modified Fuzzy Goal Programming. Finally, Solangi et al. 2019 [33] evaluated strategies for sustainable energy planning in Pakistan through an integrated SWOT-AHP and Fuzzy-TOPSIS approach. The results of the study reveal that providing low-cost and sustainable electricity to residential, commercial, and industrial sectors is a highly prioritized energy strategy.

\subsubsection{AHP}

The AHP framework is a popular tool for formulating and analyzing decisions, which is extremely useful for ranking alternatives, as well as calculating the weights of different criteria through pairwise comparisons [34]. AHP establishes a balance between quantitative and qualitative factors, as it makes it possible to incorporate judgments on intangible qualitative criteria alongside tangible quantitative criteria [35]. The AHP method is based on three basic rules/factors: first, structure of the model; second, comparative judgment of the alternatives and the criteria; third, synthesis of the priorities. Based on the above, it is clear that AHP has two main advantages: mathematical simplicity and flexibility. These two are probably the reasons why AHP is a favorite research tool in many fields, including energy management and renewable energy sources.

Available literature is abundant with examples of AHP method application in various fields, including environment and energy management [36]. Ghimire et al. 2018 [37] identified and ranked through AHP, the barriers to developing renewable energy in Nepal. Twenty-two barriers were identified and categorized into six types of barriers: social, policy and political, technical, economic, administrative, and geographic. Political instability and transportation problems are ranked first and second in overall barriers. In the same year, Ozdemir and Sahin et al. 2018 [38] examined three different locations in Turkey to find the best place for setting up a solar photovoltaic power plant through AHP, which was used to evaluate locations taking into consideration both quantitative and qualitative factors which play an effective role on the electricity production. Recently, Colak et al. 2020 [39] explored the optimal site selection for solar photovoltaic power plants using Geographic Information System (GIS) and AHP having as a case study the Malatya Province in Turkey. Keleey et al. 2018 [40] highlighted the importance of foreign direct investment (FDI) for the development of renewable energy in developing countries by using the AHP method to clarify the relative significance of the determinants in the location decisions of foreign wind and solar energy investors. Finally, Wu et al. (2019) [41] introduced a new approach using the AHP model under an interval type-2 fuzzy weighted averaging set to evaluate the performance of renewable energy projects based on the sustainability view. The results of that proposed method found that the GHG emission reduction had the best rank among other criteria.

\subsubsection{FuzzyTOPSIS}

Fuzzy multi-criteria methods constitute one approach to evaluate alternative decisions, which involve subjective judgments and are made by a group of experts. A pairwise comparison process is used to assist decision makers to make comparative judgments, while absolute judgments are made using a linguistic evaluation method [42].

TOPSIS is one of the known classical and most popular MCDM methods that was developed by Hwang and Yoon in 1981 [43]. TOPSIS is a widely accepted multi-attribute decision-making technique owing to its simultaneous consideration of the ideal and the anti-ideal solutions, and easily programmable computation procedure. Its basic principle has to do with the fact that the chosen alternative should have the shortest distance from the positive ideal solution (PIS) and the farthest from the negative ideal solution (NIS), compared to the others. Having to use crisp values is one of the weak points in the crisp evaluation process. TOPSIS method is not able to deal with decision-makers' ambiguities and uncertainties which cannot be handled by crisp values. The use of fuzzy set theory offers the decision makers the opportunity to incorporate unquantifiable information, incomplete information; non-obtainable information and partially ignorant facts into a decision model [44]. 
Consequently, fuzzy TOPSIS and its extensions are developed to solve ranking and justification problems [10,42]. It meets specific requirements when uncertain and imprecise knowledge, as well as possibly vague preferences must be considered [45]. This method allows the fuzzy values to be used in the decision problem as it offers a realistic approach by using linguistic assessments instead of numerical values $[46,47]$. Fuzzy TOPSIS method has been applied in various fields, which shows an excellent performance in the decision making of alternatives selection [48-50].

Moreover, as far as assessments in the field of energy policy are concerned, fuzzy TOPSIS has been applied in many different studies [51]. It has been also used to evaluate the viability of renewable energy projects [15]. Papapostolou et al. 2017 [10] presented a new extension of fuzzy TOPSIS method for prioritization of alternative energy policy scenarios to realize targets of renewable energy in 2030. Rani et al. 2020 [52] ranked and chose the renewable energy sources in MCDM problems based on fuzzy TOPSIS. Çolak and Kaya (2017) [53] developed a new model in order to evaluate renewable energy alternatives with the use of AHP and TOPSIS methods under interval type-2 fuzzy. According to the findings the wind energy was the best source among the available renewable energy sources. Karunathilake et al. (2019) [54] used a combination of the fuzzy TOPSIS method and life cycle thinking to select and assess different renewable energy sources. Ligus and Peternek, 2018 [55] proposed a hybrid MCDM model based on fuzzy AHP and fuzzy TOPSIS in order prioritize low-emission energy technologies development in Poland through criteria relevant to the sustainable development policy goals in Poland. The research results show that renewable energy technologies should be utilized instead of nuclear energy.

\subsection{Manuscript Organisation}

Apart from this introductory section, the rest of the paper is organized as follows. Section 2 gives an overview of the method followed for the assessment of a potential transnational cooperation in the field of RES, as well as the methodological steps of the SWOT-AHP-fuzzy TOPSIS.

Section 3 includes the application of the proposed model for the country of Morocco, as well as a comparison of the obtained results with the respective results obtained from the application in Egypt.

Section 4 includes the discussion of the results and in Section 5, the main conclusions of the paper are summarized and key points for further research are proposed.

\section{Materials and Methods}

\subsection{Overview of the Proposed Methodology}

The establishment of a successful energy cooperation with the host countries, requires the assessment of the host countries current situation, so as Europe to define the appropriate strategic plan towards this direction [7].

Consequently, there is a need to assess, through case studies analysis, the role and design of this cooperation mechanism with regards to:

1. helping Europe achieve (or overfull fill) its RES targets in a cost-effective way, and

2. helping developing countries deploy RES, firstly, to meet their increasing energy needs and, secondly, for exports to the EU.

The following figure (Figure 1) illustrates the methodology applied in order to draw the necessary conclusions considering the effectiveness of the implementation of a cross border cooperation between the EU and developing countries. 


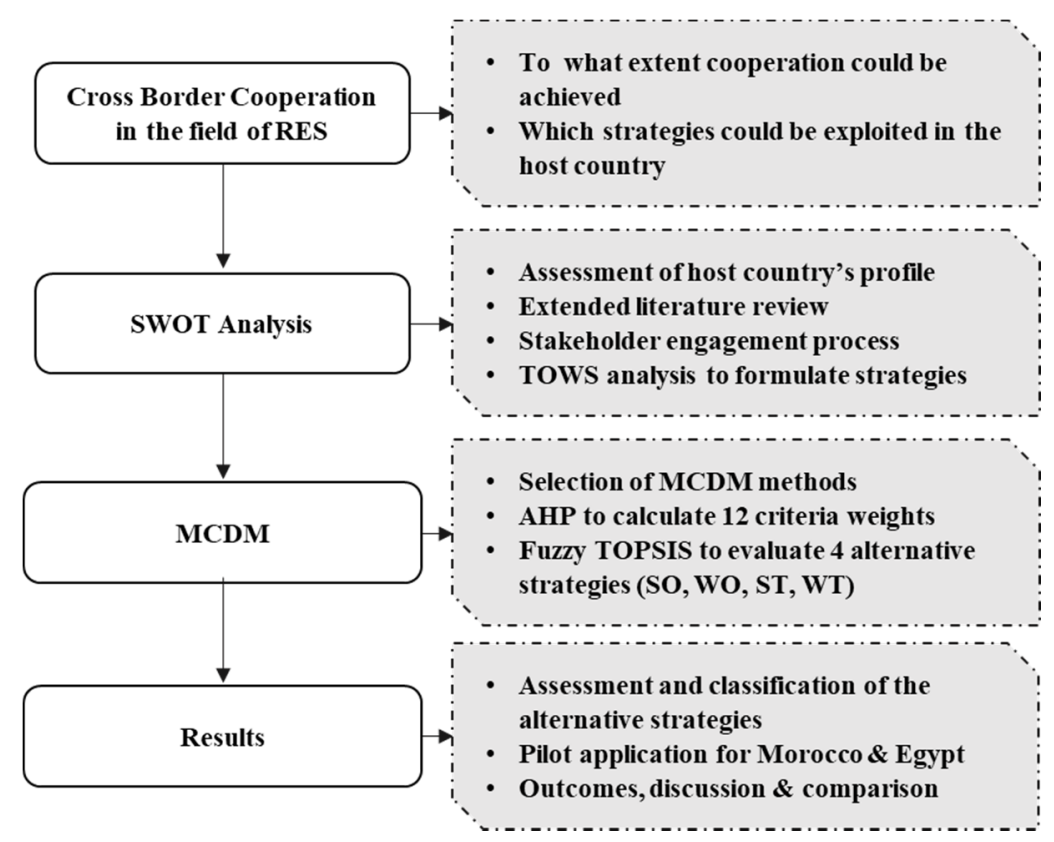

Figure 1. Proposed methodology for addressing the problem.

Firstly, the areas to be evaluated, in order to study the extent to which the neighboring countries can participate in such an energy cooperation, were identified. Then, taking these axes into account, 12 criteria were adopted, which refer to the above-mentioned axes and give a clear picture of the current situation in the country under consideration. After setting the criteria, an extensive study in the international literature and in online sources followed to gather information that characterize a host country in each of the criteria. This process was followed by the identification of the strengths, weaknesses, opportunities and threats existing in each of these 12 criteria and a SWOT analysis for the host country was completed. Finally, through Threats, Opportunities, Weaknesses and Strengths (TOWS) analysis, the four alternative strategies (SO, WO, ST, WT) were obtained [25,56,57]. The TOWS analysis has been widely used to define strategies based on a previously conducted SWOT analysis. Thus, according to the specific TOWS matrix, strategies can be developed, on the basis of the identified strengths, weaknesses, opportunities and threats [57]. More specifically the four alternative strategies are defined as:

- SO: Strategy that uses the internal strengths to take advantage of opportunities.

- ST: Strategy that uses the strengths to minimize threats.

- WO: Strategy that improves weaknesses by taking advantage of opportunities.

- WO: Strategy that tries to eliminate weaknesses to avoid threats.

Subsequently, after an extensive literature review, the most appropriate MCDM methods for the specific problem were selected. These MCDM methods were applied to assess and classify the alternative strategies from the most to the least preferable according to decision maker's preferences. Finally, after the strategies' classification, the most suitable strategy towards achieving a successful energy cross border cooperation was identified.

\subsection{Implementation Steps of the Proposed Methodology}

The basic steps of the proposed methodology consist of the following items (Figure 2). 


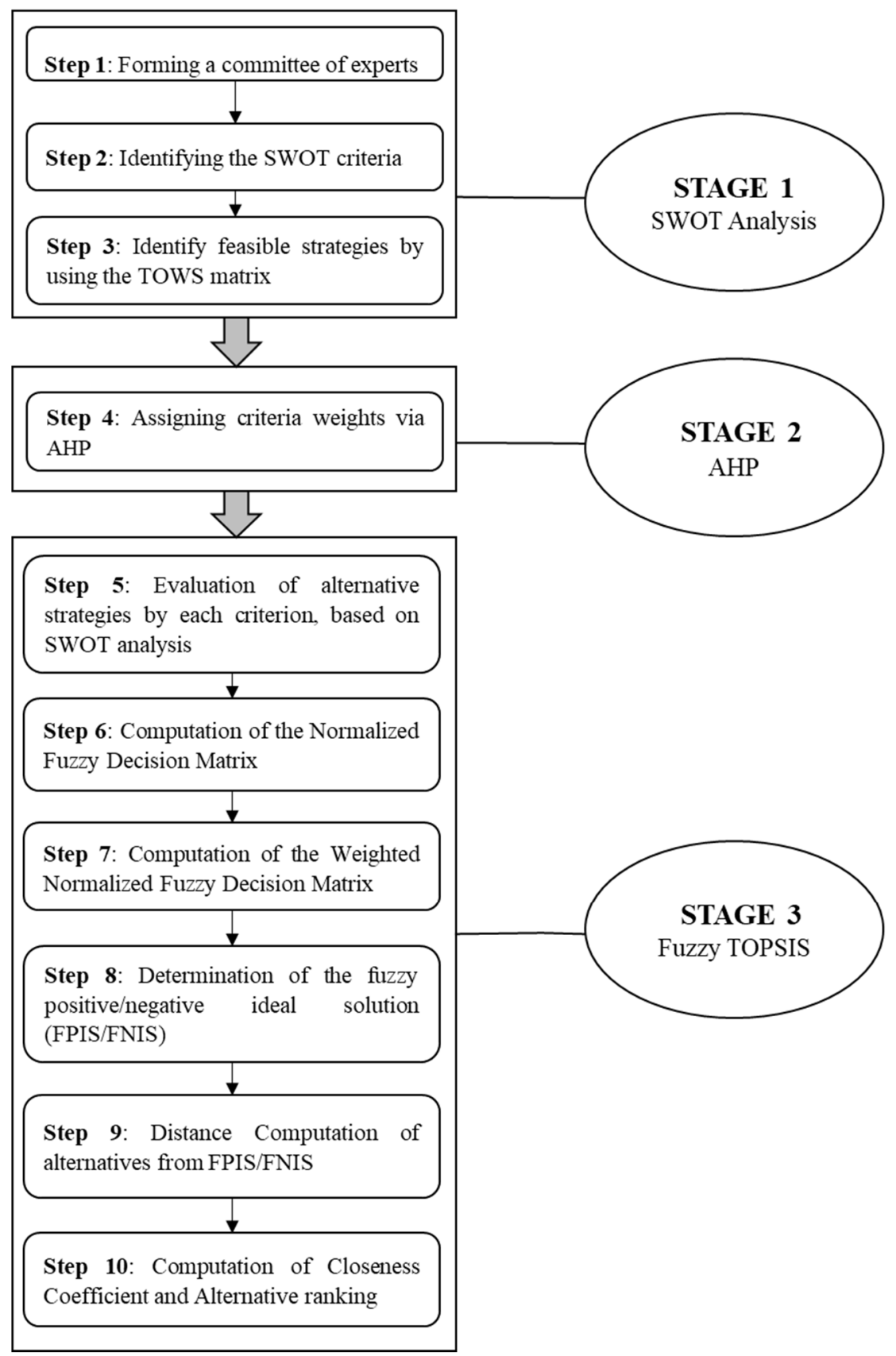

Figure 2. The proposed model.

The proposed model for the project selection problem, composed of AHP and fuzzy TOPSIS methods, consists of three basic stages: (1) SWOT Analysis completion, (2) AHP computations, (3) evaluation of alternatives with fuzzy TOPSIS and determination of the final rank.

Step 1. Forming a committee of experts

There are a number of "group-based" research techniques available to determine the views or perceptions of individuals, in relation to specific topics [58,59]. By applying the most appropriate to the case technique, at the end of this step a set of $\mathrm{K}$ decision makers are defined. Their main target is to define the problem and to examine all the different aspects of it, in detail.

Step 2. Identifying the SWOT criteria

SWOT is a powerful strategic analysis tool that combines the study of the strengths and weaknesses of an organization, territory, project or sector with the study of opportunities and threats in its environment with the aim to define a development strategy. It is worth mentioning that a project's 
strengths and weaknesses demonstrate the project's internal characteristics and are controllable; and opportunities and threats are determined by external factors on which the project has no direct control but can react to its own advantage.

Based on Karakosta et al. 2016 [9], SWOT analysis is approached differently in this paper, compared to how SWOT is typically applied to companies. More specifically, the strengths and weaknesses account for the current host country's situation assessment regarding the implementation of cooperation mechanisms, while the opportunities and threats take into account the possible future (internal and external) developments that may have the ability to change the current situation (Figure 3).

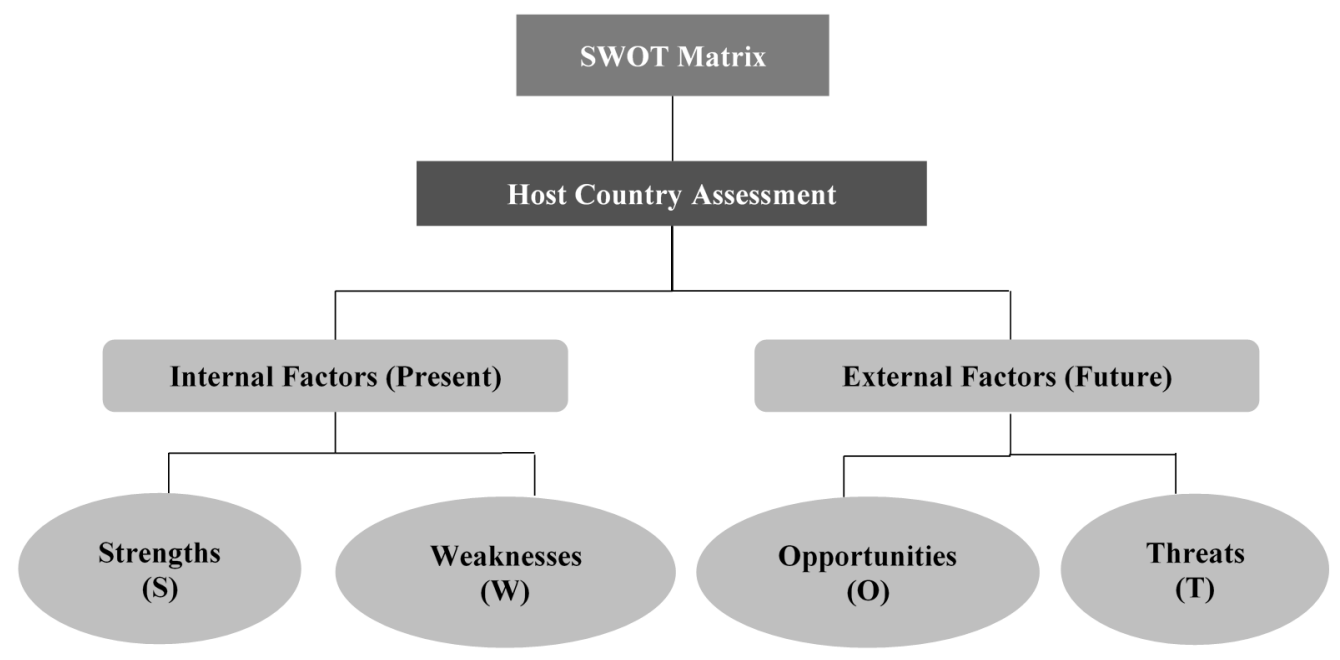

Figure 3. Strengths, Weaknesses, Opportunities and Threats (SWOT) analysis approach.

In the above context, a three-level framework is followed in order to cover important dimensions regarding the assessment of a host country for the implementation of cooperation mechanism. These three levels consist of the energy profile, the investment profile as well as the socio-environmental profile of the host country.

Firstly, the energy profile of the host country is examined. This profile includes information about the current energy situation of the host country as well as the targets set, while data on the development of RES are also presented. This profile emphasizes investment and economic factors, which characterize each country, with particular emphasis on the general framework (political, regulatory, institutional) applied by the government of the country in the energy sector. Without any political will and support and, thus, without the regulatory framework to facilitate and encourage the implementation of joint projects, investments in these projects are hardly feasible. Finally, from a socio-environmental point of view, if the public discourse is mainly characterized by oppositional groups arguing against joint projects, policy makers may not be willing to create favorable investment conditions in terms of support mechanism and regulation.

Within this three-level structure, 12 pivotal factors (criteria) were identified reflecting the favorable and non-favorable conditions for joint RES projects, between EU and neighboring countries (Figure 4). The energy profile criteria are: energy system strategy and energy outlook $\left(C_{1}\right)$, RES industry development $\left(C_{2}\right)$ and energy security $\left(C_{3}\right)$. The investment profile criteria are: market structure of energy system $\left(C_{4}\right)$, grid and Interconnections $\left(C_{5}\right), R E$ regulatory and policy framework $\left(C_{6}\right)$, institutional framework for RES-E deployment $\left(C_{7}\right)$, financial risks and uncertainty $\left(C_{8}\right)$, investment facilitation $\left(\mathrm{C}_{9}\right)$ and RES-E capacity and potential $\left(\mathrm{C}_{10}\right)$ The socio-environmental criteria are: public acceptance $\left(C_{11}\right)$ and, finally, environmental and social effects $\left(C_{12}\right)$. These assessment criteria were presented to experts and stakeholders in order to gather feedback and proceed with the SWOT analysis based on the responses received. 


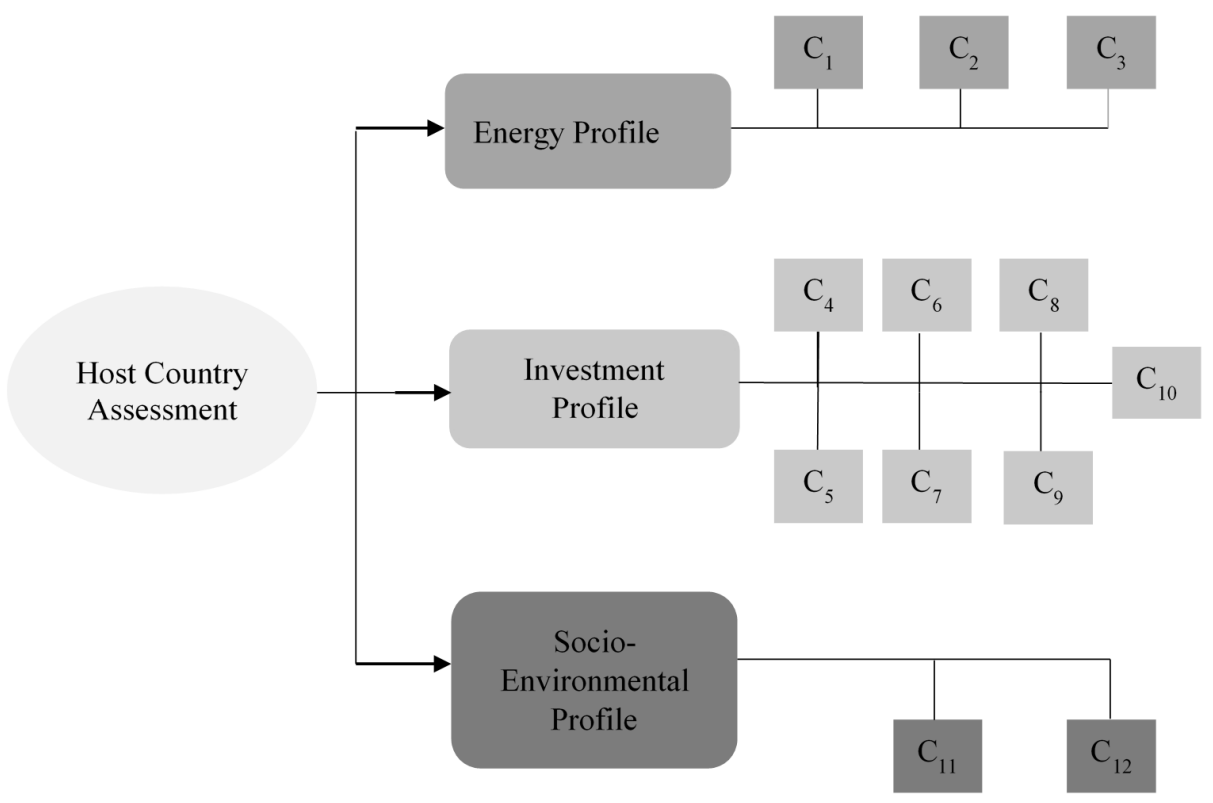

Figure 4. SWOT analysis levels and indicators.

Step 3. Identify feasible strategies by using the TOWS matrix

After identifying the strength, weakness, opportunity and threat factors, the TOWS matrix is developed based on their combinations - manifesting into four pairwise SO, ST, WO and WT of strategies (Table 1). In the strategies identified as SO, the optimal use of internal strengths and external opportunities are determined. In the strategies identified as WO, the use of external opportunities would reduce or eliminate internal weaknesses. In the strategies identified as ST, the use of internal strengths would reduce or completely eliminate external threats. For the strategies identified as WT, the decrease in external threats would be achieved by considering internal weaknesses [60]. In this paper, these four types will be assessed and ranked using MCDM methods.

Table 1. Threats, Opportunities, Weaknesses and Strengths (TOWS) analysis matrix [58].

\begin{tabular}{cccc}
\hline & & \multicolumn{2}{c}{ Internal Factors } \\
& & Strengths (S) & Weaknesses (W) \\
\hline \multirow{2}{*}{ External Factors } & Opportunities (O) & SO Strategy & WO Strategy \\
& Threats (T) & ST Strategy & WT Strategy \\
\hline
\end{tabular}

Step 4: Assigning criteria weights via AHP

In this step, the 12 criteria that are used in the problem of the host country assessment are weighted by using AHP method. In this phase, pairwise comparison matrixes are formed to determine the criteria weights. For the purpose of this study, the Saaty's nine-point scale was used [61]. The decision-making team make individual evaluations using the scale provided in Table 2, to determine the values of the elements of pairwise comparison matrixes.

Table 2. Nine-point intensity important scale.

\begin{tabular}{cc}
\hline Definition & Intensely of Importance \\
\hline Equally important & 1 \\
Moderately more important & 3 \\
Strongly more important & 5 \\
Very strong more important & 7 \\
Extremely more important & 9 \\
Intermediate more important & $2,4,6,8$ \\
\hline
\end{tabular}


Let $C=\left\{C_{j} \mid j=1,2, \ldots, n\right\}$ be the set of criteria (in this study $n=12$ ). Considering the criteria, the pairwise comparison of the criterion with the criterion $\mathrm{j}$ yields a square matrix $\widetilde{A}$ where, $\mathrm{a}_{\mathrm{ij}}$ denotes the comparative importance of criterion $i$ with respect to criterion $j$. In the matrix, $a_{i j}=1$, when $i=j$ and $\mathrm{a}_{\mathrm{ji}}=1 / \mathrm{a}_{\mathrm{ij}}$.

$$
\widetilde{A}=\left[\begin{array}{cccc}
\mathrm{a}_{11} & \mathrm{a}_{12} & \cdots & \mathrm{a}_{1 \mathrm{n}} \\
\mathrm{a}_{21} & \mathrm{a}_{22} & \cdots & \mathrm{a}_{2 \mathrm{n}} \\
\vdots & \vdots & \ddots & \vdots \\
\alpha_{\mathrm{n} 1} & \mathrm{a}_{\mathrm{n} 2} & \cdots & \alpha_{\mathrm{nn}}
\end{array}\right]
$$

The calculation of the normalized matrix $\widetilde{A}_{n}$ follows. More specifically we calculate the normalized matrix $\widetilde{A}_{n}$ by summation of each column and then dividing each element by the respective column total, where, element $c_{\mathrm{ij}}$ is the normalized element,

$$
c_{i j}=\frac{a_{i j}}{\sum_{i=1}^{n} a_{i j}}
$$

and

$$
\widetilde{A}_{n}=\left[\begin{array}{cccc}
c_{11} & c_{12} & \cdots & c_{1 n} \\
c_{21} & c_{22} & \cdots & c_{2 n} \\
\vdots & \vdots & \ddots & \vdots \\
c_{n} & c_{n 2} & \cdots & c_{n n}
\end{array}\right]
$$

Next, we calculate the mean of each row to obtain the normalized principal Eigen vector i.e.,

$$
\left[\begin{array}{c}
\frac{1}{n} \sum c_{1 j} \\
\cdot \\
\cdot \\
\cdot \\
\cdot \\
\frac{1}{n} \sum c_{n j}
\end{array}\right], \text { for } j=1,2, \ldots, n .
$$

Here, several iterations are done by squaring the normalized matrix till the difference in principal Eigen vectors in previous and iterated matrix becomes almost zero or negative. This final iterated matrix gives the principal eigen vector (or priority vector), which is the weight of each criterion. The principal eigen value of the matrix $A$ has to be calculated, it is called $\lambda_{\max }$. It is calculated by multiplying the column sums of matrix A with the principal Eigen vector (e) i.e.,

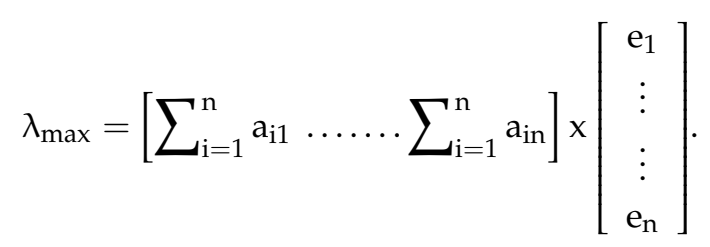

In the last step of this phase, we calculate the consistency index $(C I)=\left(\lambda_{\max }-n\right) /(n-1)$ and also obtain the Random Index (RI), for the number of criteria used in decision making, which is four $(n=12)$ for the case under consideration and the respective value of $R I=1.54$. Finally, we calculate the consistency ratio $(C R)=C I / R I$. Usually, a CR of $0.10(10 \%)$ or less is considered acceptable.

Step 5: Evaluation of alternative strategies by each criterion, based on SWOT analysis

Within this step, it is suggested that the decision maker uses the linguistic variables to evaluate the ratings of alternatives strategies, with respect to various criteria. The evaluation is based on the content of the SWOT Analysis, in each of these 12 criteria. For the evaluation of the strategies a seven-point scale has been used as presented in the Table 3. 
Table 3. Linguistic Variables and Fuzzy Numbers.

\begin{tabular}{cc}
\hline $\begin{array}{c}\text { Linguistic Variables for The Ratings } \\
\text { Funguistic Variables }\end{array}$ & $(0,0,1)$ \\
Very Poor (VP) & $(0,1,3)$ \\
Poor (P) & $(1,3,5)$ \\
Medium Poor (MP) & $(3,5,7)$ \\
Fair (F) & $(5,7,9)$ \\
Medium Good (MG) & $(7,9,10)$ \\
Good (G) & $(9,10,10)$ \\
Very Good (VG)
\end{tabular}

Step 6: Computation of the Fuzzy Decision Matrix and the Normalized Fuzzy Decision Matrix A fuzzy multi-criteria group decision making problem can be concisely expressed in matrix format as:

$$
\begin{gathered}
\widetilde{\mathrm{D}}=\left[\begin{array}{ccc}
\widetilde{\mathrm{x}}_{11} & \widetilde{\mathrm{x}}_{12} \cdots & \widetilde{\mathrm{x}}_{1 \mathrm{n}} \\
\widetilde{\mathrm{x}}_{21} & \widetilde{\mathrm{x}}_{22} & \widetilde{\mathrm{x}}_{2 \mathrm{n}} \\
\vdots & \ddots & \vdots \\
\widetilde{\mathrm{x}}_{\mathrm{m} 1} & \widetilde{\mathrm{x}}_{\mathrm{m} 2} \cdots & \widetilde{\mathrm{x}}_{\mathrm{mn}}
\end{array}\right], \\
\widetilde{\mathrm{W}}=\left[\begin{array}{ccc}
\widetilde{\mathrm{w}}_{1} & \widetilde{\mathrm{w}}_{2} \cdots & \widetilde{\mathrm{w}}_{\mathrm{n}}
\end{array}\right],
\end{gathered}
$$

where $\widetilde{x}_{i j} \forall i, j$ are linguistic variables, while $\widetilde{w}_{j}, j=1,2, \ldots, n$ are already calculated via AHP in step 4 . These linguistic variables can be described by triangular fuzzy numbers $\widetilde{x}_{i j}=\left(a_{i j}, b_{i j}, c_{i j}\right)$. To avoid the complicated normalization formula used in classical TOPSIS, the linear scale transformation is used here to transform the various criteria scales into a comparable scale. Therefore, the normalized fuzzy decision matrix denoted by $\widetilde{R}$, can be obtained.

$$
\widetilde{R}=\left[\widetilde{r}_{i j}\right]_{m \times n}
$$

where:

$$
\widetilde{r}_{i j}=\left(\frac{a_{i j}}{c_{j}^{*}}, \frac{b_{i j}}{c_{j}^{*}}, \frac{c_{i j}}{c_{j}^{*}}\right)
$$

and

$$
\begin{gathered}
c_{j}^{*}=\max _{i} c_{i j} \quad \text { benefit criteria } \\
\widetilde{r}_{i j}=\left(\frac{a_{j}^{-}}{c_{i j}}, \frac{a_{j}^{-}}{b_{i j}}, \frac{a_{j}^{-}}{a_{i j}}\right)
\end{gathered}
$$

And

$$
a_{j}^{-}=\min _{i} a_{i j} \quad \text { cost criteria }
$$

Step 7: Computation of the Weighted Normalized Fuzzy Decision Matrix

Considering the different importance of each criterion, the weighted normalized fuzzy decision matrix can be constructed as:

$$
\widetilde{V}=\left[\widetilde{v}_{i j}\right]_{m x n} i=1,2, \ldots, m ; j=1,2, \ldots, n
$$

Where

$$
\widetilde{\mathrm{u}}_{\mathrm{ij}}=\widetilde{\mathrm{r}}_{\mathrm{ij}}(.) \widetilde{\mathrm{w}}_{\mathrm{j}}
$$

Step 8: Determination of the fuzzy positive/negative ideal solution (FPIS/FNIS) 
According to the weighted normalized fuzzy decision matrix, it is evident that the elements $\widetilde{u}_{i j} \forall i$, $\mathrm{j}$ are normalized positive triangular fuzzy numbers and their ranges belong to the closed interval $[0,1]$. Then, the fuzzy positive-ideal solution (FPIS, $\mathrm{A}^{*}$ ) and the fuzzy negative-ideal (FNIS, $\mathrm{A}^{-}$) solution can be defined as:

$$
\mathrm{A}^{*}=\left(\widetilde{\mathrm{u}}_{1}^{*}, \widetilde{\mathrm{u}}_{2}^{*} \ldots, \widetilde{\mathrm{u}}_{\mathrm{n}}^{*}\right)
$$

where

$$
\begin{aligned}
\widetilde{u}_{j}^{*}=\max _{i}\left\{u_{i j 3}\right\} i & =1,2, \ldots, m ; j=1,2, \ldots, n \\
A^{-} & =\left(\widetilde{u}_{1}^{-}, \widetilde{u}_{2}^{-} \ldots, \widetilde{u}_{n}^{-}\right)
\end{aligned}
$$

Where

$$
\widetilde{u}_{j}^{-}=\min _{i}\left\{u_{i j 1}\right\} i=1,2, \ldots, m ; j=1,2, \ldots, n
$$

Step 9: Distance Computation of alternatives from FPIS/FNIS

The distance of each alternative from $\mathrm{A}^{*}$ can be currently calculated as:

$$
\mathrm{d}_{\mathrm{i}}^{*}=\sum_{\mathrm{j}=1}^{\mathrm{n}} \mathrm{d}\left(\widetilde{\mathrm{u}}_{\mathrm{ij}}, \widetilde{\mathrm{u}}_{\mathrm{j}}^{*}\right), \mathrm{i}=1,2, \ldots, \mathrm{m}
$$

The distance of each alternative from $\mathrm{A}^{-}$can be currently calculated as:

$$
\mathrm{d}_{\mathrm{i}}^{-}=\sum_{\mathrm{j}=1}^{\mathrm{n}} \mathrm{d}\left(\widetilde{\mathrm{u}}_{\mathrm{ij}}, \widetilde{\mathrm{u}}_{\mathrm{j}}^{-}\right), \mathrm{i}=1,2, \ldots, \mathrm{m}
$$

where $\mathrm{d}(.,$.$) is the distance measurement between two fuzzy numbers.$

For triangular fuzzy numbers, the distance between two fuzzy numbers $m$ and $n$ is expressed by:

$$
\mathrm{d}(\widetilde{\mathrm{m}}, \widetilde{\mathrm{n}})=\sqrt{\frac{1}{3}\left[\left(\mathrm{~m}_{1}-\mathrm{n}_{1}\right)^{2}+\left(\mathrm{m}_{2}-\mathrm{n}_{2}\right)^{2}+\left(\mathrm{m}_{3}-\mathrm{n}_{3}\right)^{2}\right]}
$$

where: $\widetilde{\mathrm{m}}=\left(\mathrm{m}_{1}, \mathrm{~m}_{2}, \mathrm{~m}_{3}\right)$ and $\widetilde{\mathrm{n}}=\left(\mathrm{n}_{1}, \mathrm{n}_{2}, \mathrm{n}_{3}\right)$.

Step 10: Computation of closeness coefficient and alternative ranking

The closeness coefficient $\mathrm{CC}_{\mathrm{i}}$ enabling the alternatives classification can be calculated as:

$$
\mathrm{CC}_{\mathrm{i}}=\frac{\mathrm{d}_{\mathrm{i}}^{-}}{\mathrm{d}_{\mathrm{i}}^{*}+\mathrm{d}_{\mathrm{i}}^{-}}, \mathrm{i}=1,2, \ldots \mathrm{m}
$$

The closeness coefficient ranges between $(0,1)$ and the alternative with the largest closeness coefficient is the ideal solution. Besides, the alternative defining the ideal solution is also the one with the shortest distance from the positive ideal solution FPIS and with the shortest distance from the negative ideal solution FNIS. Thus, the ranking of alternatives in descending order comes as a result [30].

\section{Application: The Case of Morocco}

The proposed methodology was applied to the country of Morocco in order to determine the national strategic plan for the development of a successful cross border cooperation in the field of RES. Initially, an overview of the country's current situation regarding the energy profile, the investment profile and the socio-environmental profile, is presented while the main steps of the proposed methodology and its specific implementation follow. In order to validate the results of the study, the same methodology was also applied for the case of Egypt. The results are presented and compared to those of Morocco. 


\subsection{Overview of Morocco's Current Situation}

\subsubsection{Energy Profile}

The energy sector of Morocco is characterized by many imports of fossil fuels, a fact which makes the country completely dependent on others to meet domestic energy needs [62]. It is important to mention that the strategic geographical position offers Morocco the opportunity to be a center of activity with network interconnections. In order to support this a number of actions have taken place, including legislations, the establishment of renewable energy and energy efficiency agencies and the engagement of different domestic and international stakeholders [63,64]. In the meantime, in 2016 the country hosted the United Nations Conference of Parties (COP22) summit in Marrakesh, while its government has set a new national climate policy strengthening its role in international action on climate change by transforming Morocco's energy strategy to significantly improve the country's standards and meet the goals of Paris Agreement [65].

The growing energy demand because of the growing population, combined with the lack of primary energy wealth, have led the country into an energy imbalance [66]. It should be distinctively noted that demand forecasts suggest that Morocco must double its total installed capacity of electricity from 2020 to 2030, to meet the demand, a fact which shows the current energy crisis in the country [67].

As far as the renewable energy is concerned, it offers an excellent opportunity both for the rehabilitation of the country from the imports of fossil fuels, and the prospect of green energy exports to Europe. Conversely, the constant use of conventional resources is a direct consequence of the increase of greenhouse gas emissions, which is a major domestic problem. At the end of 2018 renewable energy share in the national electricity mix reached 35\% (it is envisaged an expansion of renewable electricity to a share of $52 \%$ of installed capacity by 2030) [68]. However, while the share of renewables in electricity is progressing fast, its share in total final consumption decreased considerably over the past decade, given the expanding energy demand. To meet the challenges, the government of the country adopted an ambitious energy policy relative to the renewable energy sector, which includes targets to increase their participation in the domestic generated electricity, while the operation of both wind farms, as well as solar thermal power plants has increased [69]. The country has also made good use of the best available technologies in its large-scale concentrated solar power (CSP) projects, and pioneers innovative hybrid solutions, with photovoltaic and thermal solar storage [70]. Morocco has increased the hours of storage in its CSP plants and is investing in new interconnections and market integration with European neighbors, ensuring greater security, efficiency and flexibility of the power system [71].

The electricity selling prices remain quite low in relation to the production and transportation costs while, furthermore, stability and balancing issues of the network and energy supply problems must be solved in order to enable the successful penetration of RES in the energy sector of the country [72]. It is also worth mentioning that the power grid needs network reinforcements between south and north where the wind and solar potential are the highest. To this end, ONEE (Office National de l' Électricité et de $l^{\prime}$ Eau Potable) has, as its main aim, the grid expansion, which will also support interconnections for exports mainly across the Mediterranean [73].

\subsubsection{Investment Profile}

In an increasingly unstable international economic environment, the economy in Morocco remains robust as it has managed to resist the wider economic crisis of the past years [74]. The country's electricity market is almost fully liberalized, which can foster a potential cooperation with the European countries in the field of renewable energy while, at the same time, encouraging and attracting foreign investments is a key component of the strategy of the country. According to the latest edition of the Renewable Energy Country Attractiveness Index (RECAI) Morocco ranks $14^{\text {th }}$ among 40 countries on the attractiveness of their renewable energy investment and deployment opportunities [75].

In recent years significant progress both at the institutional level and at the legislative level has been noted, while reform efforts in the energy sector are made by reorganizing the functioning of 
ONEE [76]. Several institutional reforms have been introduced in order to support the implementation of the National Energy Strategy. The national regulatory authority (ANRE) and the Moroccan Agency for Sustainable Energy (MASEN) are dedicated to the development of integrated renewable energy projects, while The Institute for Research in Solar Energy and Renewable Energies (IRESEN) and The Agence Marocaine pour 1' Efficacité Énergétique (AMEE) are implementing projects about energy efficiency in collaboration with the private sector [71].

For Morocco, the EU is by far its biggest economic partner, accounting for well over half of its trade and investment [72]. As a result, in December 2018, a plan that accounts for a sustainable energy trading system was signed between Morocco, Germany, France, Spain and Portugal. Furthermore, Morocco launched a vast project of economic modernization program (Industrial Acceleration Plan 2014-2020) to attract more Foreign Direct Investments (FDI) [77]. Finally, at a funding level, some organizations, such as the Energy Development Fund and the Energy Investment Corporation operate with the financial support of the local RES sector [74].

As far as the renewable investments are concerned, the quality of Moroccan renewable energy resources and the attractive investment climate have resulted in lower costs for wind and solar photovoltaics, which are now competitive with the price of fossil fuel-based electricity. However, while Morocco's location is very favorable for the generation of solar and wind electricity, significant investment barriers that hinder RES-E development at scale still prevail [78]. Investors' risk perceptions are particularly high for RES-E technologies, which are characterized by high capital expenditures, and for developing countries. Nowadays, it is a big challenge for Morocco to divert current investments from conventional technologies to low-carbon, and raise additional financial resources for operationalizing the RES-E transition, given the anticipated increases in electricity demand [79].

\subsubsection{Socio-Environmental Profile}

Morocco, as is the case with most North African countries, is particularly vulnerable to climate change and the possible rise in the sea level, while there is a heavy dependence on water resources, mainly in agriculture $[80,81]$. According to the Intergovernmental Panel on Climate Change (IPCC) methodology, the development of climate scenarios for Morocco reveals a tendency to increase the mean annual temperature (between $0.6^{\circ} \mathrm{C}$ and $1.1{ }^{\circ} \mathrm{C}$ ) and decrease the mean annual volume of precipitation by about $4 \%$ in 2020 compared to 2000 levels [82].

In the social sector of the country, although good living conditions prevail in general and the growth rates are stable, some important issues remain unresolved. One of these is the high unemployment levels, which mainly affect young people [74]. However, a new Country Partnership Framework for Morocco (CPF) was designed to support Morocco's efforts at improving social cohesion and reducing social and territorial disparities and was discussed by the Board of Executive Directors on February 19, 2019. Covering the Fiscal years 2019 to 2024, it has the overarching goal of contributing to social cohesion by improving the conditions for growth and job creation and reducing social and territorial disparities [83].

In this direction, the benefits the community of the country will reap on the development of RES are important and for this reason it is considered necessary to design action planning for further information and for the awareness of the public [84].

\subsection{Application of the Proposed Methodology}

The main steps of the proposed methodology and its specific implementation are given below for the case of Morocco:

Steps 1-2-3: Based on the abovementioned methodology, in this research the experts' team, which acted as the decision maker for the problem, used twelve different criteria $C_{j}, j=\{1,2,3,4,5,6,7,8,9,10,11,12\}$, in order to assess different types of strategies. The main goal is, on the one hand, to identify which of these strategies is the most suitable for developing energy cooperation between EU and Morocco, and on the other hand, to recognize how strengths, weaknesses, opportunities and threats should be used 
towards this direction. It is worth mentioning that for each one of these 12 criteria, a SWOT analysis has been conducted considering an extended literature review, examining potential opportunities and barriers that promote or hinder the development and implementation of cooperation mechanisms in the country.

After determining the strengths, weaknesses, opportunities, and threats for each of the abovementioned criteria, four alternative strategies were identified from the SWOT analysis. More specifically, these strategies are SO, WO, ST as well as WT. This paper aims to assess which type, is the most appropriate for developing an energy cooperation with Morocco, after taking under consideration the information provided by the SWOT analysis, in each of the 12 criteria. Morocco's SWOT Analysis is presented in the following figure (Figure 5).

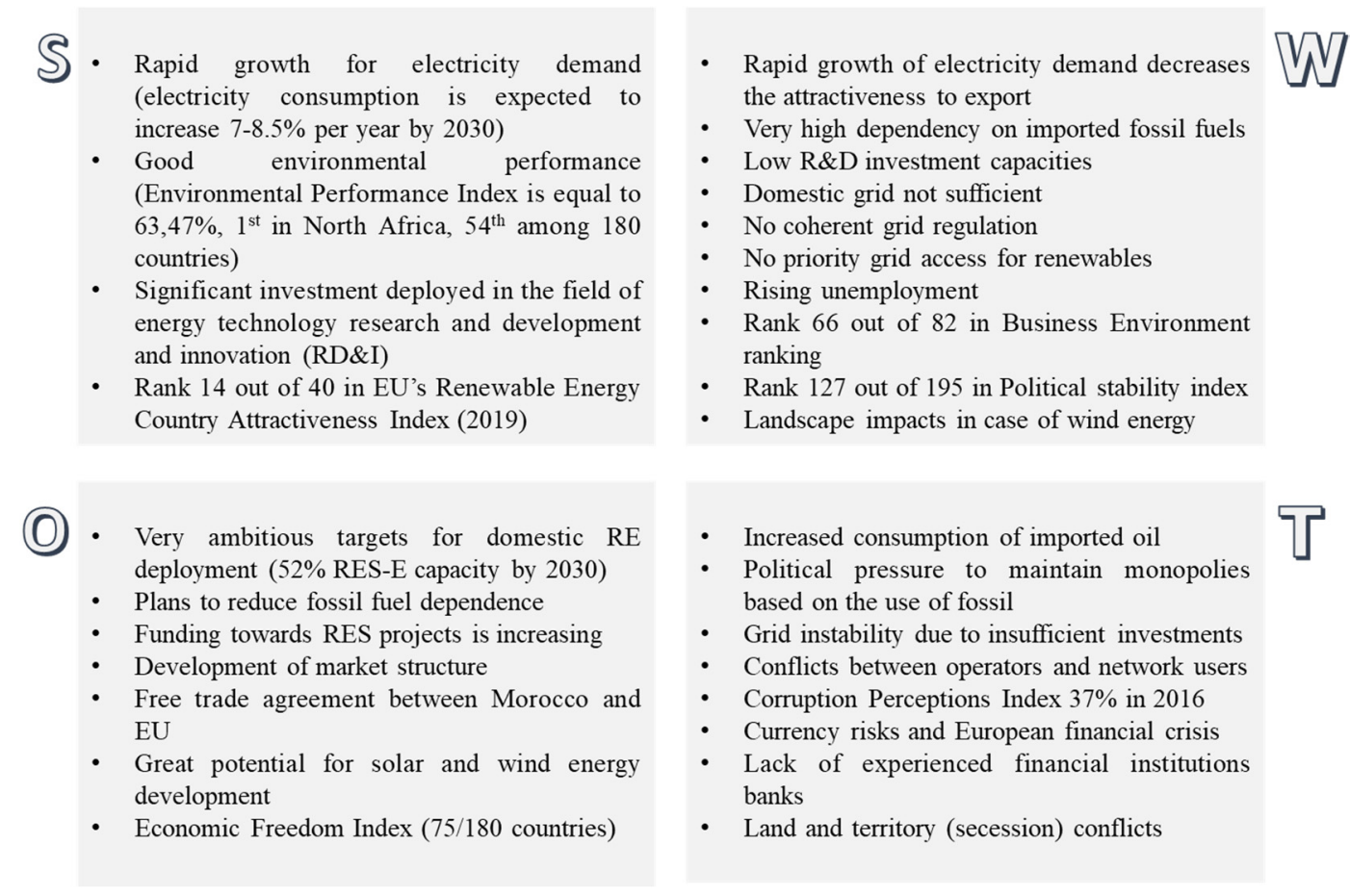

Figure 5. SWOT Analysis for Morocco.

EU and Moroccan stakeholders' involvement was the key guarantee that the proper questions were addressed, that assumptions were valid and that results were meaningful and could open opportunities for market development.

It should be mentioned that the experts' team that played the role of the decision maker in our study was identified and selected to participate in the evaluation process within the framework of the project "Bringing Europe and Third countries closer together through renewable Energies (BETTER)", started in July 2012 and ended in 2015 and carried out under the Intelligent Energy Europe program [84]. BETTER intends to address RES cooperation between the EU and neighboring developing countries in several dimensions. Within the framework of the BETTER project, North Africa countries were examined as far as their potential in developing cooperation mechanisms. To this end, relevant stakeholders were engaged through a stakeholder consultation process. Bilateral meetings with experts in the field, as well as stakeholders' workshops provided feedback to the SWOT analysis and the importance of our evaluation criteria.

Step 4: In this step, the weights of the criteria used in the evaluation process are calculated with the use of the AHP method. In this phase, the decision maker is given the task of forming individual pairwise comparison matrix (Table 4), by using the scale given in Table 2. 
Table 4. Matrix for criteria (pairwise comparison).

\begin{tabular}{|c|c|c|c|c|c|c|c|c|c|c|c|c|}
\hline$C_{i}$ & $C_{1}$ & $\mathrm{C}_{2}$ & $\mathrm{C}_{3}$ & $\mathrm{C}_{4}$ & $\mathrm{C}_{5}$ & $\mathrm{C}_{6}$ & $\mathrm{C}_{7}$ & $\mathrm{C}_{8}$ & $\mathrm{C}_{9}$ & $\mathrm{C}_{10}$ & $\mathrm{C}_{11}$ & $C_{12}$ \\
\hline$C_{1}$ & 1 & $1 / 4$ & $1 / 4$ & $1 / 5$ & $1 / 2$ & $1 / 7$ & $1 / 7$ & $1 / 6$ & $1 / 5$ & $1 / 8$ & $1 / 3$ & 2 \\
\hline $\mathrm{C}_{2}$ & 4 & 1 & 1 & $1 / 2$ & 3 & $1 / 4$ & $1 / 4$ & $1 / 3$ & $1 / 2$ & $1 / 5$ & 2 & 5 \\
\hline $\mathrm{C}_{3}$ & 4 & 1 & 1 & $1 / 2$ & 3 & $1 / 4$ & $1 / 4$ & $1 / 3$ & $1 / 2$ & $1 / 5$ & 2 & 5 \\
\hline $\mathrm{C}_{4}$ & 5 & 2 & 2 & 1 & 4 & $1 / 3$ & $1 / 3$ & $1 / 2$ & 1 & $1 / 4$ & 3 & 6 \\
\hline $\mathrm{C}_{5}$ & 2 & $1 / 3$ & $1 / 3$ & $1 / 4$ & 1 & $1 / 6$ & $1 / 6$ & $1 / 5$ & $1 / 4$ & $1 / 7$ & $1 / 2$ & 3 \\
\hline $\mathrm{C}_{6}$ & 7 & 4 & 4 & 3 & 6 & 1 & 1 & 2 & 3 & $1 / 2$ & 5 & 8 \\
\hline $\mathrm{C}_{7}$ & 7 & 4 & 4 & 3 & 6 & 1 & 1 & 2 & 3 & $1 / 2$ & 5 & 8 \\
\hline $\mathrm{C}_{8}$ & 6 & 3 & 3 & 2 & 5 & $1 / 2$ & $1 / 2$ & 1 & 2 & $1 / 3$ & 4 & 7 \\
\hline $\mathrm{C}_{9}$ & 5 & 2 & 2 & 1 & 4 & $1 / 3$ & $1 / 3$ & $1 / 2$ & 1 & $1 / 4$ & 3 & 6 \\
\hline $\mathrm{C}_{10}$ & 8 & 5 & 5 & 4 & 7 & 2 & 2 & 3 & 4 & 1 & 6 & 9 \\
\hline $\mathrm{C}_{11}$ & 3 & $1 / 2$ & $1 / 2$ & $1 / 3$ & 2 & $1 / 5$ & $1 / 5$ & $1 / 4$ & $1 / 3$ & $1 / 6$ & 1 & 4 \\
\hline $\mathrm{C}_{12}$ & $1 / 2$ & $1 / 5$ & $1 / 5$ & $1 / 6$ & $1 / 3$ & $1 / 8$ & $1 / 8$ & $1 / 7$ & $1 / 6$ & $1 / 9$ & $1 / 4$ & 1 \\
\hline
\end{tabular}

Then, the normalization of the pairwise comparison matrix follows (Table 5).

Table 5. Normalized matrix for criteria.

\begin{tabular}{ccccccccccccc}
\hline $\mathbf{C}_{\mathbf{i}}$ & $\mathbf{C}_{\mathbf{1}}$ & $\mathbf{C}_{\mathbf{2}}$ & $\mathbf{C}_{\mathbf{3}}$ & $\mathbf{C}_{\mathbf{4}}$ & $\mathbf{C}_{\mathbf{5}}$ & $\mathbf{C}_{\mathbf{6}}$ & $\mathbf{C}_{\mathbf{7}}$ & $\mathbf{C}_{\mathbf{8}}$ & $\mathbf{C}_{\mathbf{9}}$ & $\mathbf{C}_{\mathbf{1 0}}$ & $\mathbf{C}_{\mathbf{1 1}}$ & $\mathbf{C}_{\mathbf{1 2}}$ \\
\hline $\mathrm{C}_{1}$ & 0.019 & 0.011 & 0.011 & 0.013 & 0.012 & 0.023 & 0.023 & 0.016 & 0.013 & 0.033 & 0.010 & 0.031 \\
$\mathrm{C}_{2}$ & 0.076 & 0.043 & 0.043 & 0.031 & 0.072 & 0.040 & 0.040 & 0.032 & 0.031 & 0.053 & 0.062 & 0.078 \\
$\mathrm{C}_{3}$ & 0.076 & 0.043 & 0.043 & 0.031 & 0.072 & 0.040 & 0.040 & 0.032 & 0.031 & 0.053 & 0.062 & 0.078 \\
$\mathrm{C}_{4}$ & 0.095 & 0.086 & 0.086 & 0.063 & 0.100 & 0.053 & 0.053 & 0.048 & 0.063 & 0.066 & 0.094 & 0.094 \\
$\mathrm{C}_{5}$ & 0.038 & 0.014 & 0.014 & 0.016 & 0.023 & 0.026 & 0.026 & 0.019 & 0.016 & 0.038 & 0.016 & 0.047 \\
$\mathrm{C}_{6}$ & 0.133 & 0.172 & 0.172 & 0.188 & 0.143 & 0.159 & 0.159 & 0.192 & 0.188 & 0,132 & 0.156 & 0.125 \\
$\mathrm{C}_{7}$ & 0.133 & 0.172 & 0.172 & 0.188 & 0.143 & 0.159 & 0.159 & 0.192 & 0,188 & 0.132 & 0.156 & 0.125 \\
$\mathrm{C}_{8}$ & 0.114 & 0.129 & 0.129 & 0.125 & 0.120 & 0.079 & 0.079 & 0.096 & 0.125 & 0.088 & 0.125 & 0.109 \\
$\mathrm{C}_{9}$ & 0.095 & 0.086 & 0.086 & 0.063 & 0.100 & 0.053 & 0.053 & 0.048 & 0.063 & 0.066 & 0.094 & 0.094 \\
$\mathrm{C}_{10}$ & 0.152 & 0.215 & 0.215 & 0.251 & 0.167 & 0.317 & 0.317 & 0.288 & 0.251 & 0.265 & 0.187 & 0.141 \\
$\mathrm{C}_{11}$ & 0.057 & 0.021 & 0.021 & 0.021 & 0.048 & 0.032 & 0.032 & 0.024 & 0.021 & 0.044 & 0.031 & 0.063 \\
$\mathrm{C}_{12}$ & 0.01 & 0.009 & 0.009 & 0.010 & 0.008 & 0.020 & 0.020 & 0.014 & 0.010 & 0.030 & 0.008 & 0.016 \\
\hline
\end{tabular}

The results obtained from the computations based on the pairwise comparison matrix provided in Table 5, are presented in Table 6, which includes the final results of AHP.

Table 6. Results obtained by Analytic Hierarchy Process (AHP).

\begin{tabular}{cccccc}
\hline Criteria & $\mathbf{w}_{\mathbf{i}}$ & $\boldsymbol{\lambda}_{\max }$ & $\mathbf{R I}$ & $\mathbf{C I}$ & $\mathbf{C R}$ \\
\hline $\mathrm{C}_{1}$ & $1.8 \%$ & & & & \\
$\mathrm{C}_{2}$ & $5 \%$ & & & & \\
$\mathrm{C}_{3}$ & $5 \%$ & & & & \\
$\mathrm{C}_{4}$ & $7.5 \%$ & & & & \\
$\mathrm{C}_{5}$ & $2.4 \%$ & & & & \\
$\mathrm{C}_{6}$ & $16 \%$ & 12.68 & 1.54 & 0.062 & 0.04 \\
$\mathrm{C}_{7}$ & $16 \%$ & & & & \\
$\mathrm{C}_{8}$ & $11 \%$ & & & & \\
$\mathrm{C}_{9}$ & $7.5 \%$ & & & & \\
$\mathrm{C}_{10}$ & $23 \%$ & & & & \\
$\mathrm{C}_{11}$ & $3.5 \%$ & & & & \\
$\mathrm{C}_{12}$ & $1.3 \%$ & & & & \\
\hline
\end{tabular}

According to Table 6, the consistency ratio of the pairwise comparison matrix is calculated as 0.04 $<0.1$. Therefore, the weights are shown to be consistent and they are used in the strategy assessment process. Based on the weights presented in the second column of Table 6 , the final rank of the criteria is presented (Table 7). 
Table 7. Final rank of the criteria.

\begin{tabular}{ccc}
\hline Criteria & Weight & Final Rank \\
\hline RES-E capacity and potential $\left(\mathrm{C}_{10}\right)$ & 0.23 & 1 \\
RE regulatory and policy framework $\left(\mathrm{C}_{6}\right)$ & 0.16 & 2 \\
Institutional framework for RES-E deployment $\left(\mathrm{C}_{7}\right)$ & 0.16 & 2 \\
Financial risks and uncertainty $\left(\mathrm{C}_{8}\right)$ & 0.11 & 3 \\
Market structure of energy system $\left(\mathrm{C}_{4}\right)$ & 0.075 & 4 \\
Investment facilitation $\left(\mathrm{C}_{9}\right)$ & 0.075 & 4 \\
RES industry development $\left(\mathrm{C}_{2}\right)$ & 0.05 & 5 \\
Energy Security $\left(\mathrm{C}_{3}\right)$ & 0.05 & 5 \\
Social Acceptance $\left(\mathrm{C}_{11}\right)$ & 0.035 & 6 \\
Grid and Interconnections $\left(\mathrm{C}_{5}\right)$ & 0.024 & 7 \\
Energy System Strategy and Energy Outlook $\left(\mathrm{C}_{1}\right)$ & 0.018 & 8 \\
Environmental and social effects $\left(\mathrm{C}_{12}\right)$ & 0.013 & 9 \\
\hline
\end{tabular}

In the following figure (Figure 6) the importance of the criteria according to decision maker judgment is depicted in a radar chart.

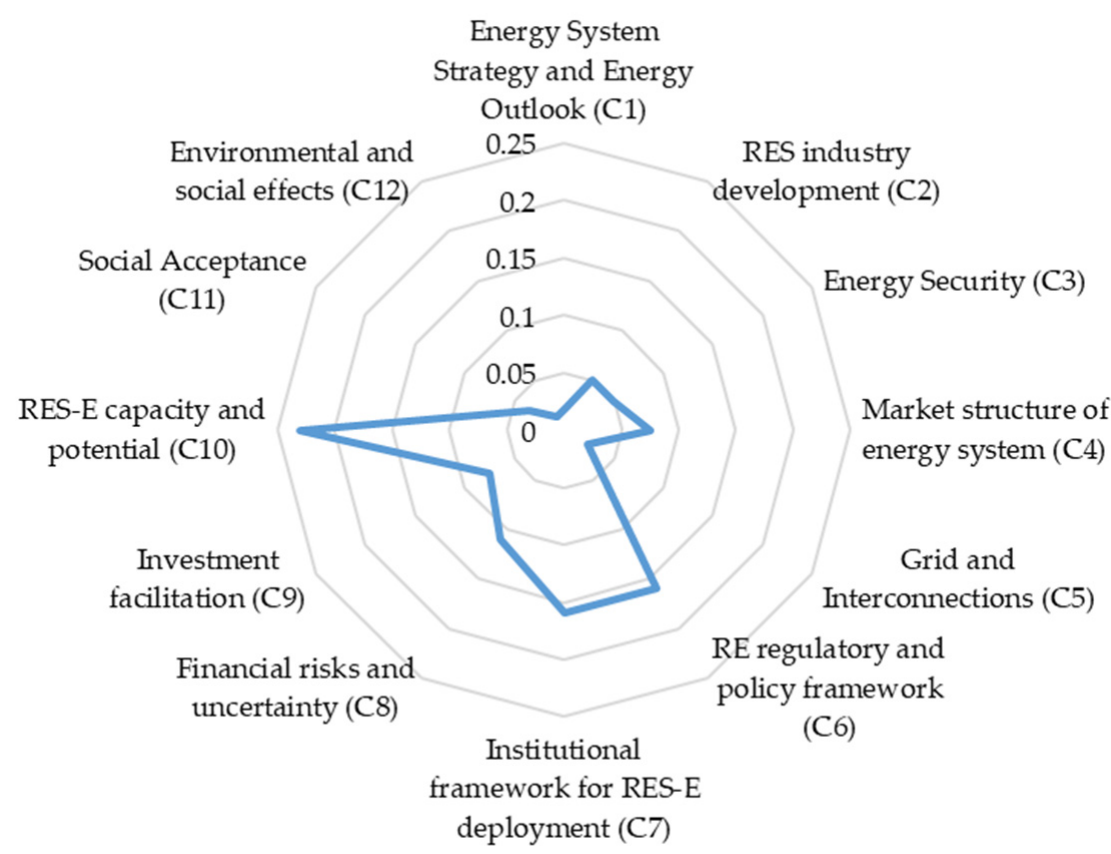

Figure 6. Evaluation criteria weights.

Step 5: Through the Fuzzy TOPSIS, the linguistic variables are defined to evaluate the ratings of alternatives with respect to these criteria. Using a seven-point scale transformation for the alternatives' ratings $S=(V P, P, M P, F, M G, G, V G)$ the linguistic variables can be converted into fuzzy numbers. Thus, the calibrated conversion scales were constructed through which the four alternative strategies for each of the 12 criteria were evaluated.

Based on the aforementioned scale, the decision maker assessed the alternative policy strategies at EU level to each one of the criteria, taking into account the Morocco's SWOT analysis (Tables 8 and 9). 
Table 8. Ratings of the alternative strategies by the decision maker

\begin{tabular}{|c|c|c|c|c|}
\hline Criteria & SO & WO & ST & WT \\
\hline $\mathrm{C}_{1}$ & VG & G & $\mathrm{F}$ & MG \\
\hline $\mathrm{C}_{2}$ & MG & $\mathrm{F}$ & $\mathrm{MP}$ & $\mathrm{F}$ \\
\hline $\mathrm{C}_{3}$ & MG & $\mathrm{MP}$ & $\mathrm{MP}$ & $\mathrm{F}$ \\
\hline $\mathrm{C}_{4}$ & MG & $\mathrm{F}$ & $\mathrm{P}$ & VP \\
\hline $\mathrm{C}_{5}$ & VG & $\mathrm{F}$ & MG & MP \\
\hline $\mathrm{C}_{6}$ & G & $\mathrm{MP}$ & MG & MP \\
\hline $\mathrm{C}_{7}$ & G & MG & $\mathrm{F}$ & $\mathrm{P}$ \\
\hline $\mathrm{C}_{8}$ & MG & $\mathrm{F}$ & $\mathrm{F}$ & MP \\
\hline $\mathrm{C}_{9}$ & MG & $\mathrm{MP}$ & $\mathrm{F}$ & $\mathrm{P}$ \\
\hline $\mathrm{C}_{10}$ & G & MG & MG & MP \\
\hline$C_{11}$ & $\mathrm{~F}$ & $\mathrm{MP}$ & $\mathrm{MP}$ & $\mathrm{F}$ \\
\hline $\mathrm{C}_{12}$ & MG & MP & $\mathrm{F}$ & F \\
\hline
\end{tabular}

Table 9. Fuzzy decision matrix.

\begin{tabular}{ccccc}
\hline Criteria & SO & WO & ST & WT \\
\hline$C_{1}$ & $(9,10,10)$ & $(7,9,10)$ & $(3,5,7)$ & $(5,7,9)$ \\
$C_{2}$ & $(5,7,9)$ & $(3,5,7)$ & $(1,3,5)$ & $(3,5,7)$ \\
$C_{3}$ & $(5,7,9)$ & $(1,3,5)$ & $(1,3,5)$ & $(3,5,7)$ \\
$C_{4}$ & $(5,7,9)$ & $(3,5,7)$ & $(0,1,3)$ & $(0,0,1)$ \\
$C_{5}$ & $(9,10,10)$ & $(3,5,7)$ & $(5,7,9)$ & $(1,3,5)$ \\
$C_{6}$ & $(7,9,10)$ & $(1,3,5)$ & $(5,7,9)$ & $(1,3,5)$ \\
$C_{7}$ & $(7,9,10)$ & $(5,7,9)$ & $(3,5,7)$ & $(0,1,3)$ \\
$C_{8}$ & $(5,7,9)$ & $(3,5,7)$ & $(3,5,7)$ & $(1,3,5)$ \\
$C_{9}$ & $(5,7,9)$ & $(1,3,5)$ & $(3,5,7)$ & $(0,1,3)$ \\
$C_{10}$ & $(7,9,10)$ & $(5,7,9)$ & $(5,7,9)$ & $(1,3,5)$ \\
$C_{11}$ & $(3,5,7)$ & $(1,3,5)$ & $(1,3,5)$ & $(3,5,7)$ \\
$C_{12}$ & $(5,7,9)$ & $(1,3,5)$ & $(3,5,7)$ & $(3,5,7)$ \\
\hline
\end{tabular}

Step 6: In this step the normalized fuzzy decision matrix (Table 10) is calculated.

Table 10. Normalized fuzzy decision Matrix

\begin{tabular}{ccccc}
\hline Criteria & SO & WO & ST & WT \\
\hline$C_{1}$ & $(0.9,1,1)$ & $(0.7,0.9,1)$ & $(0.3,0.5,0.7)$ & $(0.5,0.7,0.9)$ \\
$C_{2}$ & $(0.55,0.77,1)$ & $(0.33,0.55,0.77)$ & $(0.11,0.33,0.55)$ & $(0.33,0.55,0.77)$ \\
$C_{3}$ & $(0.55,0.77,1)$ & $(0.11,0.33,0.55)$ & $(0.11,0.33,0.55)$ & $(0.33,0.55,0.77)$ \\
$C_{4}$ & $(0.55,0.77,1)$ & $(0.33,0.55,0.77)$ & $(0,0.11,0.33)$ & $(0,0,0.11)$ \\
$C_{5}$ & $(0.9,1,1)$ & $(0.3,0.5,0.7)$ & $(0.5,0.7,0.9)$ & $(0.1,0.3,0.5)$ \\
$C_{6}$ & $(0.7,0.9,1)$ & $(0.1,0.3,0.5)$ & $(0.5,0.7,0.9)$ & $(0.1,0.3,0.5)$ \\
$C_{7}$ & $(0.7,0.9,1)$ & $(0.5,0.7,0.9)$ & $(0.3,0.5,0.7)$ & $(0,0.1,0.3)$ \\
$C_{8}$ & $(0.55,0.77,1)$ & $(0.33,0.55,0.77)$ & $(0.33,0.55,0.77)$ & $(0.11,0.33,0.55)$ \\
$C_{9}$ & $(0.55,0.77,1)$ & $(0.11,0.33,0.55)$ & $(0.33,0.55,0.77)$ & $(0,0.11,0.33)$ \\
$C_{10}$ & $(0.7,0.9,1)$ & $(0.5,0.7,0.9)$ & $(0.5,0.7,0.9)$ & $(0.1,0.3,0.5)$ \\
$C_{11}$ & $(0.42,0.71,1)$ & $(0.14,0.42,0.71)$ & $(0.14,0.42,0.71)$ & $(0.42,0.71,1)$ \\
$C_{12}$ & $(0.55,0.77,1)$ & $(0.11,0.33,0.55)$ & $(0.33,0.55,0.77)$ & $(0.33,0.55,0.77)$ \\
\hline
\end{tabular}

Step 7: According to step 7, the weights $\left(\mathrm{W}_{\mathrm{i}}\right)$ calculated via AHP and presented in Table 7 , were used for the calculation of the weighted normalized fuzzy decision matrix (Table 11). 
Table 11. Weighted normalized fuzzy decision matrix.

\begin{tabular}{ccccc}
\hline Criteria & SO & WO & ST & WT \\
\hline $\mathrm{C}_{1}$ & $(0.016,0.018,0.018)$ & $(0.013,0.016,0.018)$ & $(0.005,0.009,0.013)$ & $(0.009,0.013,0.016)$ \\
$\mathrm{C}_{2}$ & $(0.028,0.039,0.050)$ & $(0.017,0.028,0.039)$ & $(0.006,0.017,0.028)$ & $(0.017,0.028,0.039)$ \\
$\mathrm{C}_{3}$ & $(0.028,0.039,0.050)$ & $(0.006,0.017,0.028)$ & $(0.006,0.017,0.028)$ & $(0.017,0.028,0.039)$ \\
$\mathrm{C}_{4}$ & $(0.041,0.058,0.075)$ & $(0.025,0.041,0.058)$ & $(0.000,0.008,0.025)$ & $(0.000,0.000,0.008)$ \\
$\mathrm{C}_{5}$ & $(0.022,0.024,0.024)$ & $(0.007,0.012,0.017)$ & $(0.012,0.017,0.022)$ & $(0.002,0.007,0.012)$ \\
$\mathrm{C}_{6}$ & $(0.112,0.144,0.160)$ & $(0.016,0.048,0.080)$ & $(0.080,0.112,0.144)$ & $(0.016,0.048,0.080)$ \\
$\mathrm{C}_{7}$ & $(0.112,0.144,0.160)$ & $(0.080,0.112,0.144)$ & $(0.048,0.080,0.112)$ & $(0.000,0.016,0.048)$ \\
$\mathrm{C}_{8}$ & $(0.061,0.085,0.110)$ & $(0.036,0.061,0.085)$ & $(0.036,0.061,0.085)$ & $(0.012,0.036,0.061)$ \\
$\mathrm{C}_{9}$ & $(0.041,0.058,0.075)$ & $(0.008,0.025,0.041)$ & $(0.025,0.041,0.058)$ & $(0.000,0.008,0.025)$ \\
$\mathrm{C}_{10}$ & $(0.161,0.207,0.230)$ & $(0.115,0.161,0.207)$ & $(0.115,0.161,0.207)$ & $(0.023,0.069,0.115)$ \\
$\mathrm{C}_{11}$ & $(0.015,0.025,0.035)$ & $(0.005,0.015,0.025)$ & $(0.005,0.015,0.025)$ & $(0.015,0.025,0.035)$ \\
$\mathrm{C}_{12}$ & $(0.007,0.010,0.013)$ & $(0,001,0,004,0,007)$ & $(0,004,0,007,0,010)$ & $(0.004,0.007,0.010)$ \\
\hline
\end{tabular}

Step 8: It is observed that the elements that construct the Table 11 are normalized positive triangular fuzzy numbers and their ranges belong to the closed interval [0,1]. Thus, the fuzzy positive-ideal solution (FPIS, $\mathrm{A}^{*}$ ) and the fuzzy negative-ideal solution (FNIS, A-) are defined as $\mathrm{A}^{*}=$ $(1,1,1)$ and $A^{-}=(0,0,0)$ for benefit criterion, and $A^{*}=(0,0,0)$ and $A^{-}=(1,1,1)$ for cost criterion. In this study, all criteria are considered as benefit criteria.

Step 9: The distance of each alternative from the positive ideal solution FPIS, $\mathrm{d}\left(\mathrm{Aj}, \mathrm{A}^{*}\right)$, and the negative ideal solution FNIS, $\mathrm{d}(\mathrm{Aj}, \mathrm{A}-)$, are presented below (Tables 12 and 13):

Table 12. Distances from the positive ideal solution (FPIS).

\begin{tabular}{ccccc}
\hline Criteria & SO & WO & ST & WT \\
\hline $\mathrm{C}_{1}$ & 0.983 & 0.984 & 0.991 & 0.987 \\
$\mathrm{C}_{2}$ & 0.961 & 0.973 & 0.984 & 0.973 \\
$\mathrm{C}_{3}$ & 0.961 & 0.984 & 0.984 & 0.973 \\
$\mathrm{C}_{4}$ & 0.942 & 0.959 & 0.989 & 0.997 \\
$\mathrm{C}_{5}$ & 0.977 & 0.988 & 0.983 & 0.993 \\
$\mathrm{C}_{6}$ & 0.862 & 0.952 & 0.888 & 0.952 \\
$\mathrm{C}_{7}$ & 0.862 & 0,888 & 0.920 & 0.979 \\
$\mathrm{C}_{8}$ & 0.915 & 0.940 & 0.940 & 0.964 \\
$\mathrm{C}_{9}$ & 0.942 & 0.975 & 0.959 & 0.989 \\
$\mathrm{C}_{10}$ & 0.801 & 0.840 & 0.840 & 0.932 \\
$\mathrm{C}_{11}$ & 0.979 & 0.985 & 0.982 & 0.987 \\
$\mathrm{C}_{12}$ & 0.990 & 0.996 & 0.993 & 0.993 \\
$\mathrm{~A}^{*}$ & 11.175 & 11.464 & 11.453 & 11.719 \\
\hline
\end{tabular}

Table 13. Distances from the negative ideal solution (FNIS).

\begin{tabular}{ccccc}
\hline Criteria & SO & WO & ST & WT \\
\hline $\mathrm{C}_{1}$ & 0.017 & 0.016 & 0.009 & 0.013 \\
$\mathrm{C}_{2}$ & 0.040 & 0.029 & 0.019 & 0.029 \\
$\mathrm{C}_{3}$ & 0.040 & 0.019 & 0.019 & 0.029 \\
$\mathrm{C}_{4}$ & 0.060 & 0.043 & 0.015 & 0.005 \\
$\mathrm{C}_{5}$ & 0.023 & 0.013 & 0.017 & 0.008 \\
$\mathrm{C}_{6}$ & 0.140 & 0.055 & 0.115 & 0.055 \\
$\mathrm{C}_{7}$ & 0.140 & 0.115 & 0.084 & 0.029 \\
$\mathrm{C}_{8}$ & 0.087 & 0.064 & 0.064 & 0.041 \\
$\mathrm{C}_{9}$ & 0.060 & 0.028 & 0.043 & 0.015 \\
$\mathrm{C}_{10}$ & 0.201 & 0.165 & 0.165 & 0.079 \\
$\mathrm{C}_{11}$ & 0.022 & 0.017 & 0.022 & 0.017 \\
$\mathrm{C}_{12}$ & 0.010 & 0.005 & 0.008 & 0.008 \\
$\mathrm{~A}-$ & 0.840 & 0.569 & 0.580 & 0.328 \\
\hline
\end{tabular}


Step 10: Through the equation (FPIS, FNIS) and the application of the Euclidean distance of each alternative from $A^{*}$ and $A^{-}$, the closeness coefficient is calculated, enabling the alternatives ranking (Table 14). As a result, the closeness coefficient can indicate which alternative strategy is optimal for achieving an energy cooperation with Morocco and which are the crucial factors (Strengths, Weaknesses, Opportunities, Threats) that the EU should capitalize on.

Table 14. Alternative strategies ranking for the case of Morocco with use of closeness coefficient.

\begin{tabular}{cccc}
\hline Ranking & $\mathbf{A}_{\mathbf{i}}$ & Alternative Strategies & Closeness Coefficient \\
\hline $\mathbf{1}$ & $\mathrm{A}_{1}$ & $\mathrm{SO}$ & 0.07 \\
$\mathbf{3}$ & $\mathrm{A}_{2}$ & $\mathrm{WO}$ & 0.047 \\
$\mathbf{2}$ & $\mathrm{A}_{3}$ & $\mathrm{ST}$ & 0.048 \\
$\mathbf{4}$ & $\mathrm{A}_{4}$ & $\mathrm{WT}$ & 0.027 \\
\hline
\end{tabular}

The final ranking is described as $\mathrm{A}_{1}>\mathrm{A}_{3}>\mathrm{A}_{2}>\mathrm{A}_{4}$ and highlights as the best, the alternative strategy $\mathrm{A}_{1}$ "Strategy SO", since the closeness coefficient of the alternative $\mathrm{A}_{1}$ is closer to one and thus the largest over others Pilot Application in Egypt: Results

In order to validate the results of the proposed methodology, it has been also applied to the case study of Egypt, so as to compare the strategies that are proposed in both countries, according to the decision maker judgments. Of course, the criteria weights as they are assessed in Step 4 of the proposed methodology through the AHP method, are the same for both case studies, since it captures the significance of the identified factors in terms of RES-E cooperation deployment in a host country.

Egypt represents the region's most populated energy market and is the largest oil and gas consumer in the continent. Of the total primary energy consumption in Egypt, $94 \%$ is from fossil fuels, while some energy comes from hydropower. [85]. This strong dependence on fossil fuels is mainly due to the strong subsidies on fossil energy utilities imposed so far, which caused a vulnerability of the country to socio-economic events, resulting in low levels of reliability and security of supply [86]. The natural decline of the deposits due to their continued use in the generation process, as well as the aging of the infrastructure and the inadequate generation and transmission capacity are some of the features of the country's energy sector [87]. In addition, domestic electricity demand is growing rapidly.

There has been a change in domestic energy policy in recent years as, in order to meet these challenges, the country recognizes the need to diversify the energy mix and improve energy security through renewables [88]. For this reason, the government has adopted the so-called "Egypt's Vision 2030", which includes various goals in the direction of sustainable development with a time horizon of 2030 [89]. In addition, Egypt, with its excellent prospects due to its geographical location, plans a brave increase in electricity from renewable energy beyond 2030. It is also worth mentioning that Egyptian Electricity Transmission Company (EETC) signed a framework agreement with Euro Africa Interconnector Company to connect the power grids of Egypt, Cyprus and Greece through Crete by a 2000-megawatts (MW) electricity interconnection, which, of course, is in favor of the need for cooperation mechanism establishment.

As far as the institutional framework is concerned, laws, regulations and implementation schemes already exist that support the wind and solar sectors. However, project developers are not encouraged to implement investments due to complex administrative procedures, including the unavailability of contractual documents for projects and multiple focal points for renewable energy deployment [90]. To overcome these risks, institutional roles should be further defined.

At the social level, Egypt can greatly benefit from the development of alternative sources of energy as the socio-economic benefits they bring are unquestionable. The country is familiar with RES technologies and especially with regards to wind energy, as actions have already been taken. However, the country's limited industrial development coupled with the imbalance between demand and supply of electricity, are factors that slow down potential cooperation with other countries as the growing domestic needs have to be firstly met [84]. 
Based on the Egypt profile, the decision maker assessed the alternative policy strategies at EU level to each one of the criteria (Table 15).

Table 15. Ratings of the alternative strategies by the DM for the case of Egypt.

\begin{tabular}{|c|c|c|c|c|}
\hline Criteria & SO & WO & ST & WT \\
\hline$C_{1}$ & VG & G & MG & $\mathrm{F}$ \\
\hline $\mathrm{C}_{2}$ & MG & $\mathrm{F}$ & $\mathrm{F}$ & MG \\
\hline$C_{3}$ & $\mathrm{~F}$ & MG & $\mathrm{P}$ & $\mathrm{F}$ \\
\hline $\mathrm{C}_{4}$ & G & $\mathrm{F}$ & MG & MP \\
\hline $\mathrm{C}_{5}$ & VG & MG & $\mathrm{F}$ & $\mathrm{F}$ \\
\hline $\mathrm{C}_{6}$ & MG & MG & $\mathrm{F}$ & MP \\
\hline $\mathrm{C}_{7}$ & $\mathrm{~F}$ & MG & MP & $\mathrm{P}$ \\
\hline $\mathrm{C}_{8}$ & MG & MP & $\mathrm{F}$ & MG \\
\hline $\mathrm{C}_{9}$ & MG & MP & MG & $\mathrm{F}$ \\
\hline $\mathrm{C}_{10}$ & G & MG & MG & VP \\
\hline $\mathrm{C}_{11}$ & MG & MG & $\mathrm{F}$ & $\mathrm{P}$ \\
\hline $\mathrm{C}_{12}$ & $\mathrm{~F}$ & $\mathrm{P}$ & VP & MG \\
\hline
\end{tabular}

After the implementation of the Fuzzy TOPSIS method to evaluate the alternative strategies in Egypt, the ranking is presented in Table 16.

Table 16. Alternative strategies ranking for the case of Egypt.

\begin{tabular}{cccc}
\hline Ranking & $\mathbf{A}_{\mathbf{i}}$ & Alternative Strategies & Closeness Coefficient \\
\hline $\mathbf{1}$ & $\mathrm{A}_{1}$ & $\mathrm{SO}$ & 0.0648 \\
$\mathbf{2}$ & $\mathrm{A}_{2}$ & WO & 0.0547 \\
$\mathbf{3}$ & $\mathrm{A}_{3}$ & $\mathrm{ST}$ & 0.0478 \\
$\mathbf{4}$ & $\mathrm{A}_{4}$ & $\mathrm{WT}$ & 0.030 \\
\hline
\end{tabular}

In the case of Egypt, the final ranking is described as $A_{1}>A_{2}>A_{3}>A_{4}$ and proposed as the more preferable strategies, the $\mathrm{SO}$ and $\mathrm{WO}$ as resulted from the calculation of the closeness coefficient.

The following figure (Figure 7) illustrates the results of the implementation of the proposed methodology in the case study of Morocco and Egypt.

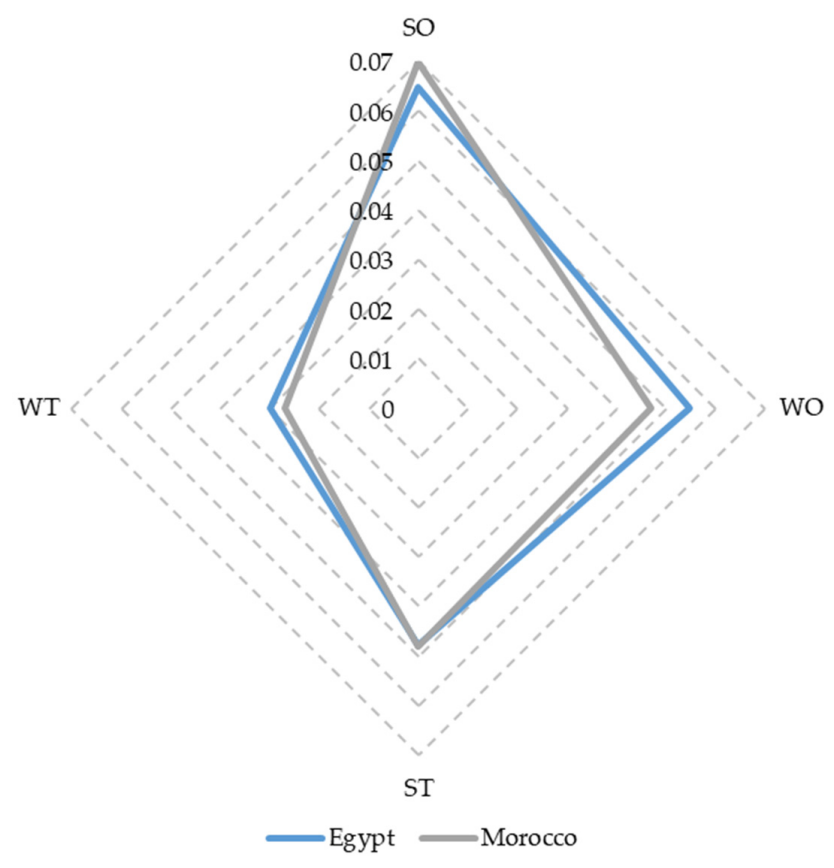

Figure 7. Results for Morocco and Egypt. 


\section{Discussion}

To sum up, in this study the preferences of the decision-making team were determined through a SWOT analysis, while the AHP method was utilized to identify their priorities towards these preferences and set weights to the specific criteria. TOWS analysis and fuzzy TOPSIS method resulted in a final ranking of four alternative strategic policy directions. This combination collects and evaluates all the different aspects of the problem simultaneously, while it also provides a flexible environment for the decision maker, in order to dynamically formulate the judgments and to manage properly the diverse and conceptually different criteria. Given the SWOT analysis of a host country, the decision makers gain insights into the internal and external factors (current and future) that play a crucial role towards cooperation, while the use of linguistic variables significantly facilitate the decision making process, as it allows for flexible mapping of their preferences.

Based on the application of the AHP method, the criterion with the greatest significance to the specific problem is $\mathrm{C}_{10}$ (RES-E capacity and potential). This criterion includes all the factors related to each country's potential and capability to develop RES and the progress achieved in the integration of technologies related to this field. Given that the EU's desire is to import renewable energy quantities from developing countries, while simultaneously to transfer expertise and make investments for the sustainable development of these countries, it is understood how important this criterion is for policy makers.

According to the final ranking of criteria, it is obvious that the criteria that cover areas, such as economy, entrepreneurship and investments are of particular value to the decision maker. If a host country does not perform well in these sectors, then a cross border energy cooperation with the EU is unlikely to happen. This is the reason why the criteria that represent these sectors, such as the RE regulatory and policy framework $\left(\mathrm{C}_{6}\right)$, the institutional framework for RES-E deployment $\left(C_{7}\right)$, financial risks and uncertainty $\left(C_{8}\right)$, the market structure of energy system $\left(C_{4}\right)$ and investment facilitation $\left(\mathrm{C}_{9}\right)$, have a higher ranking compared to other criteria.

In general, according to the results from the pilot application in Morocco, it is possible to draw some very important conclusions in evaluating the possibility of implementing an EU-Morocco cross border cooperation within the field of renewable energy. The same stands also for the case of Egypt.

Using the proposed methodology, the overall rankings for all possible strategies were determined, and finally, SO policy strategy, which addresses strengths and opportunities, prevailed in the case of Morocco. This means that EU policy makers should focus on policy strategies that explore how the strengths could be used to benefit from external opportunities. An offensive strategy (ST) is placed second, which explores how policy makers could benefit from the strengths of Morocco to avoid or lessen (potential) external threats that may hinder the implementation of cooperation. This result reveals that according to a decision maker's opinion, the strengths of the country could easily come up against the potential threats. Morocco presents a very balanced picture on all three levels of analysis, as its energy sector is relatively well developed and targets are set for increasing the share of renewable energy in the future. It is the only African country that has electrical connection with Europe, while the domestic network is relatively integrated. At the same time, the appropriate energy laws on RES have been enacted, while the country's market is accessible to potential investors. The risk levels are relatively low, while good social conditions prevail and this fact facilitates the acceptance of new energy projects, as long as these materialize in the country. Finally, the more defensive policy strategies WT and WO are not so popular in the particular problem area. This means that it is not a priority for the decision maker to try to mitigate the internal weaknesses so as to exploit opportunities or to minimize any weaknesses to avoid potential threats.

On the other hand, the application of the proposed methodology in Egypt reveals that the most preferable strategies are the $\mathrm{SO}$ and $\mathrm{WO}$, with the SO strategy that uses the internal strengths to take advantage of opportunities prevailing in both case study countries. The country already has the necessary legislation in place to support RES and the gradual penetration of RES into the energy reality, as the domestic market is largely liberalized, and the energy sector has seen slight growth in recent 
years. The country's economy is characterized by levels of volatility mainly due to monetary policy, while the investment sector has seen significant improvement through various reforms. However, the country has significant opportunities for RES development, as also described in its energy plan, which explains that the SO strategy dominates, followed by the WO which suggests using these opportunities to meet potential challenges. According to the decision makers evaluation, the country has a relatively manageable number of elements that may hinder potential energy co-operation. Thus, the existence of the ST and WT strategies in the last two ranking positions indicates that the country should rely mainly on its future potential for RES development and investment attractiveness. It seems that this country is eligible to develop cooperation with the EU, mainly because of future prospects and opportunities identified and not because of the advantages and strengths in the energy and investment sector during recent years.

\section{Conclusions}

This paper conducted a preference analysis based on the combination of SWOT analysis with two multi-criteria methods, AHP and fuzzy TOPSIS, in order to assess several factors that play a crucial role in the implementation of cross border cooperation in the field of RES and propose strategic directions towards the successful implementation. The methodology was applied for the case of Morocco and Egypt.

According to the results, Morocco performs well in most of the criteria and, thus the strategy that ranked first was the alternative $\mathrm{SO}$ with the focus to use strengths so as to exploit opportunities. On the other hand, the results from the application in Egypt reveal that the favorable strategic options that may boost the implementation of the EU-Egypt cooperation are the strategies that will try to exploit the opportunities of the country. This means that the current status of Egypt, compared to that of Morocco may not be so efficient to promote Egypt as a host country. However, future prospects seem very exploitable, and thus a defensive and an offensive strategy, based both on the exploitation of future opportunities, are ranked in the first two places.

The proposed decision-making approach is able to manage the uncertainty, inaccuracy and complexity of decisions, as they emerge from the various different and conflicting criteria. In order to ensure further improvement of the decision model, more criteria could be used to perform a more thorough analysis of the options available, as well as to include more information regarding the country concerned (e.g., Current Account Balance Index, the Energy Development Index, the Global Competitiveness Index etc.). The proposed methodological framework could also be applicable to more than one decision maker by adjusting and using the AHP and Fuzzy TOPSIS methods for group decision making. This will provide even greater accuracy and objectivity in the methodology, as it will contain different and often controversial judgments. Last but not least, this methodology could be applied to other potential host countries, such as the Western Balkans and Turkey and assist EU policy makers mapping the important factors, as well as hazards in the neighboring countries, that may emerge from a potential cooperation in the field of RES.

\section{Patents}

This section is not mandatory but may be added if there are patents resulting from the work reported in this manuscript.

Author Contributions: Conceptualization, A.P. and C.K.; Methodology, A.P., C.K. and G.A.; Writing-Original Draft Preparation, A.P. and G.A.; Writing-Review and Editing, C.K., H.D. and A.P.; Visualization, A.P. and G.A.; Supervision, H.D. All authors have read and agreed to the published version of the manuscript.

Funding: This research received no external funding.

Conflicts of Interest: The authors declare no conflict of interest. 


\section{Abbreviations and Variable Definitions}

The following abbreviations are used in this manuscript:

$\begin{array}{ll}\text { AHP } & \text { Analytic Hierarchy Process } \\ \text { AMEE } & \text { Agence Marocaine pour l' Efficacité Énergétique } \\ \text { ANP } & \text { Analytic Network Process } \\ \text { ANRE } & \text { National Agency for Regulation of Electricity } \\ \text { BETTER } & \text { Bringing Europe and Third countries closer together through renewable Energies } \\ \text { BRI } & \text { Belt and Road Initiative } \\ \text { CNG } & \text { Compressed Natural Gas } \\ \text { CPF } & \text { Country Partnership Framework } \\ \text { CSP } & \text { Concentrated Solar Power } \\ \text { EC } & \text { European Commission } \\ \text { EETC } & \text { Egyptian Electricity Transmission Company } \\ \text { FDI } & \text { Foreign Direct Investment } \\ \text { Fuzzy TOPSIS } & \text { Fuzzy Technique for Order of Preference by Similarity to Ideal Solution } \\ \text { GHG } & \text { Greenhouse Gasses } \\ \text { GIS } & \text { Geographic Information System } \\ \text { IPCC } & \text { Intergovernmental Panel on Climate Change } \\ \text { IRESEN } & \text { Institute for Research in Solar Energy and Renewable Energies } \\ \text { MASEN } & \text { Moroccan Agency for Sustainable Energy } \\ \text { MCDM } & \text { Multi-Criteria Decision Making } \\ \text { NIS } & \text { Negative Ideal Solution } \\ \text { ONEE } & \text { Office National de l' Électricité et de l' Eau Potable } \\ \text { PIS } & \text { Positive Ideal Solution } \\ \text { RECAI } & \text { Renewable Energy Country Attractiveness Index } \\ \text { RED } & \text { Renewable Energy Directive } \\ \text { RES } & \text { Renewable Energy Sources } \\ \text { RES-E } & \text { RES electricity } \\ \text { SWOT } & \text { Strengths, Weaknesses, Opportunities, Threats } \\ & \end{array}$

The following variable definitions are used in this manuscript:

$\widetilde{A_{n}} \quad$ The normalisation of the square matrix $\widetilde{A}$ :

$\widetilde{D} \quad$ The fuzzy decision matrix

$\mathrm{d}_{\mathrm{i}}^{-} \quad$ The distance of alternatives from FNIS

$\mathrm{d}_{\mathrm{i}}^{*} \quad$ The distance of alternatives from FPIS

$\widetilde{R} \quad$ The normalized fuzzy decision matrix

$\widetilde{V} \quad$ The weighted normalized fuzzy decision matrix

$\widetilde{W} \quad$ The weights of the criteria

$\widetilde{A} \quad$ The square matrix that is developed from the pairwise comparison of the criterion $\mathrm{i}$ with the criterion $\mathrm{j}$

C The set of the evaluation criteria

CC Closeness Coefficient

CI Consistency Index

CR Consistency Ratio

FNIS The fuzzy negative ideal solution

FPIS The fuzzy positive ideal solution

RI Random Index

$\lambda_{\max }$ The principal eigen value of the matrix $\widetilde{A}$

\section{References}

1. Doukas, H.; Nikas, A. Decision Support Models in Climate Policy. Eur. J. Oper. Res. 2020, $280,1-24$. [CrossRef]

2. European Commision. Clean Energy for All Europeans; COM(2016) 860 Final: Brussels, Belgium, 2016; p. 13. 
3. European Commision. Directive (EU) 2018/2001 of the European Parliament and of the Council of 11 December 2018 on the Promotion of the Use of Energy from Renewable Sources; Official Journal of the European Union: Luxembourg, 2018; p. 128.

4. Klinge Jacobsen, H.; Pade, L.L.; Schröder, S.T.; Kitzing, L. Cooperation Mechanisms to Achieve EU Renewable Targets. Renew. Energy 2014, 63, 345-352. [CrossRef]

5. Karakosta, C.; Marinakis, V.; Psarras, J. RES Cooperation Opportunities between EU and MENA Countries: The Case of Morocco. Energy Strateg. Rev. 2013, 2, 92-99. [CrossRef]

6. Papapostolou, A.; Karakosta, C.; Nikas, A.; Psarras, J. Exploring Opportunities and Risks for RES-E Deployment under Cooperation Mechanisms between EU and Western Balkans: A Multi-Criteria Assessment. Renew. Sustain. Energy Rev. 2017, 80, 519-530. [CrossRef]

7. Karakosta, C.; Marinakis, V.; Papapostolou, A.; Psarras, J. Benefits and costs sharing through RES electricity cooperation between Europe and third countries. In Proceeding of the 3rd International Conference on Energy Systems and Technologies, Cairo, Egypt, 16-19 February 2015.

8. Papapostolou, A.; Karakosta, C.; Marinakis, V.; Flamos, A. Assessment of RES Cooperation Framework between the EU and North Africa. Int. J. Energy Sect. Manag. 2016, 10, 402-426. [CrossRef]

9. Karakosta, C.; Papapostolou, A.; Dede, P.; Marinakis, V.; Psarras, J. Investigating EU-Turkey Renewable Cooperation Opportunities: A SWOT Analysis. Int. J. Energy Sect. Manag. 2016, 10, 337-362. [CrossRef]

10. Papapostolou, A.; Karakosta, C.; Doukas, H. Analysis of Policy Scenarios for Achieving Renewable Energy Sources Targets: A Fuzzy TOPSIS Approach. Energy Environ. 2017, 28, 88-109. [CrossRef]

11. Papapostolou, A.; Karakosta, C.; Kourti, K.-A.; Doukas, H.; Psarras, J. Supporting Europe's Energy Policy Towards a Decarbonised Energy System: A Comparative Assessment. Sustainability 2019, 11, 4010. [CrossRef]

12. Cinelli, M.; Coles, S.R.; Kirwan, K. Analysis of the Potentials of Multi Criteria Decision Analysis Methods to Conduct Sustainability Assessment. Ecol. Indic. 2014, 46, 138-148. [CrossRef]

13. Kumar, A.; Sah, B.; Singh, A.R.; Deng, Y.; He, X.; Kumar, P.; Bansal, R.C. A Review of Multi Criteria Decision Making (MCDM) towards Sustainable Renewable Energy Development. Renew. Sustain. Energy Rev. 2017, 69, 596-609. [CrossRef]

14. Lee, H.-C.; Chang, C.-T. Comparative Analysis of MCDM Methods for Ranking Renewable Energy Sources in Taiwan. Renew. Sustain. Energy Rev. 2018, 92, 883-896. [CrossRef]

15. Şengül, Ü.; Eren, M.; Eslamian Shiraz, S.; Gezder, V.; Şengül, A.B. Fuzzy TOPSIS Method for Ranking Renewable Energy Supply Systems in Turkey. Renew. Energy 2015, 75, 617-625. [CrossRef]

16. Stein, E.W. A Comprehensive Multi-Criteria Model to Rank Electric Energy Production Technologies. Renew. Sustain. Energy Rev. 2013, 22, 640-654. [CrossRef]

17. Wang, J.-J.; Jing, Y.-Y.; Zhang, C.-F.; Zhao, J.-H. Review on Multi-Criteria Decision Analysis Aid in Sustainable Energy Decision-Making. Renew. Sustain. Energy Rev. 2009, 13, 2263-2278. [CrossRef]

18. Kousksou, T.; Allouhi, A.; Belattar, M.; Jamil, A.; El Rhafiki, T.; Zeraouli, Y. Morocco's Strategy for Energy Security and Low-Carbon Growth. Energy 2015, 84, 98-105. [CrossRef]

19. Helms, M.M.; Nixon, J. Exploring SWOT Analysis-Where Are We Now? J. Strateg. Manag. 2010, 3, $215-251$. [CrossRef]

20. Chiu, A.S.; Yong, G. On the Industrial Ecology Potential in Asian Developing Countries. J. Clean. Prod. 2004, 12, 1037-1045. [CrossRef]

21. Terrados, J.; Almonacid, G.; Hontoria, L. Regional Energy Planning through SWOT Analysis and Strategic Planning Tools. Renew. Sustain. Energy Rev. 2007, 11, 1275-1287. [CrossRef]

22. Zharan, K.; Bongaerts, J.C. Decision-Making on the Integration of Renewable Energy in the Mining Industry: A Case Studies Analysis, a Cost Analysis and a SWOT Analysis. J. Sustain. Min. 2017, 16, 162-170. [CrossRef]

23. Jaber, J.O.; Elkarmi, F.; Alasis, E.; Kostas, A. Employment of Renewable Energy in Jordan: Current Status, SWOT and Problem Analysis. Renew. Sustain. Energy Rev. 2015, 49, 490-499. [CrossRef]

24. Chen, W.-M.; Kim, H.; Yamaguchi, H. Renewable Energy in Eastern Asia: Renewable Energy Policy Review and Comparative SWOT Analysis for Promoting Renewable Energy in Japan, South Korea, and Taiwan. Energy Policy 2014, 74, 319-329. [CrossRef]

25. Dyson, R.G. Strategic Development and SWOT Analysis at the University of Warwick. Eur. J. Oper. Res. 2004, 152, 631-640. [CrossRef] 
26. Lei, Y.; Lu, X.; Shi, M.; Wang, L.; Lv, H.; Chen, S.; Hu, C.; Yu, Q.; da Silveira, S.D.H. SWOT Analysis for the Development of Photovoltaic Solar Power in Africa in Comparison with China. Environ. Impact Assess. Rev. 2019, 77, 122-127. [CrossRef]

27. Agyekum, E.B.; Ansah, M.N.S.; Afornu, K.B. Nuclear Energy for Sustainable Development: SWOT Analysis on Ghana's Nuclear Agenda. Energy Rep. 2020, 6, 107-115. [CrossRef]

28. Kamran, M.; Fazal, M.R.; Mudassar, M. Towards Empowerment of the Renewable Energy Sector in Pakistan for Sustainable Energy Evolution: SWOT Analysis. Renew. Energy 2020, 146, 543-558. [CrossRef]

29. Igliński, B.; Iglińska, A.; Koziński, G.; Skrzatek, M.; Buczkowski, R. Wind Energy in Poland - History, Current State, Surveys, Renewable Energy Sources Act, SWOT Analysis. Renew. Sustain. Energy Rev. 2016, 64, 19-33. [CrossRef]

30. Ervural, C.B.; Zaim, S.; Demirel, O.F.; Aydin, Z.; Delen, D. An ANP and Fuzzy TOPSIS-Based SWOT Analysis for Turkey's Energy Planning. Renew. Sustain. Energy Rev. 2018, 82, 1538-1550. [CrossRef]

31. Wang, Y.; Xu, L.; Solangi, Y.A. Strategic Renewable Energy Resources Selection for Pakistan: Based on SWOT-Fuzzy AHP Approach. Sustain. Cities Soc. 2020, 52, 101861. [CrossRef]

32. Khan, M.I. Evaluating the Strategies of Compressed Natural Gas Industry Using an Integrated SWOT and MCDM Approach. J. Clean. Prod. 2018, 172, 1035-1052. [CrossRef]

33. Solangi, Y.A.; Tan, Q.; Mirjat, N.H.; Ali, S. Evaluating the Strategies for Sustainable Energy Planning in Pakistan: An Integrated SWOT-AHP and Fuzzy-TOPSIS Approach. J. Clean. Prod. 2019, 236, 117655. [CrossRef]

34. Velasquez, M.; Hester, P.T. An Analysis of Multi-Criteria Decision Making Methods. Int. J. Oper. Res. 2013, 10, 56-66.

35. Badri, M.A. A Combined AHP-GP Model for Quality Control Systems. Int. J. Prod. Econ. 2001, 72, 27-40. [CrossRef]

36. Wang, B.; Song, J.; Ren, J.; Li, K.; Duan, H.; Wang, X. Selecting Sustainable Energy Conversion Technologies for Agricultural Residues: A Fuzzy AHP-VIKOR Based Prioritization from Life Cycle Perspective. Resour. Conserv. Recycl. 2019, 142, 78-87. [CrossRef]

37. Ghimire, L.P.; Kim, Y. An Analysis on Barriers to Renewable Energy Development in the Context of Nepal Using AHP. Renew. Energy 2018, 129, 446-456. [CrossRef]

38. Ozdemir, S.; Sahin, G. Multi-Criteria Decision-Making in the Location Selection for a Solar PV Power Plant Using AHP. Measurement 2018, 129, 218-226. [CrossRef]

39. Colak, H.E.; Memisoglu, T.; Gercek, Y. Optimal Site Selection for Solar Photovoltaic (PV) Power Plants Using GIS and AHP: A Case Study of Malatya Province, Turkey. Renew. Energy 2020, 149, 565-576. [CrossRef]

40. Keeley, A.R.; Matsumoto, K. Relative Significance of Determinants of Foreign Direct Investment in Wind and Solar Energy in Developing Countries-AHP Analysis. Energy Policy 2018, 123, 337-348. [CrossRef]

41. Wu, Y.; Xu, C.; Ke, Y.; Tao, Y.; Li, X. Portfolio Optimization of Renewable Energy Projects under Type-2 Fuzzy Environment with Sustainability Perspective. Comput. Ind. Eng. 2019, 133, 69-82. [CrossRef]

42. Karakosta, C.; Psarras, J. Fuzzy TOPSIS approach for understanding a country's development priorities within the scope of climate technology transfer. In Advances in Energy Research; Acosta, M.J., Ed.; Nova Science Publishers: Hauppauge, NY, USA, 2012; Volume 9, pp. 123-149. ISBN 978-1-61470-485-0.

43. Hwang, C.L.; Yoon, K. Multiple Attribute Decision Making: Methods and Applications a State-of-the-Art Survey; Springer: Berlin/Heidelberg, Germany, 1981; ISBN 978-3-540-10558-9.

44. Zadeh, L.A. Fuzzy Sets. Inf. Control 1965, 8, 338-353. [CrossRef]

45. Kahraman, C.; Onar, S.C.; Oztaysi, B. Fuzzy Multicriteria Decision-Making: A Literature Review. Int. J. Comput. Intell. Syst. 2015, 8, 637-666. [CrossRef]

46. Bellman, R.E.; Zadeh, L.A. Decision-Making in a Fuzzy Environment. Manag. Sci. 1970, 17, B-141-B-164. [CrossRef]

47. Karakosta, C. Multi-Criteria Decision Making Methods for Technology Transfer; LAP LAMBERT Academic Publishing: Riga, Latvia, 2018; ISBN 978-613-9-86527-7.

48. Khalili-Damghani, K.; Sadi-Nezhad, S.; Tavana, M. Solving Multi-Period Project Selection Problems with Fuzzy Goal Programming Based on TOPSIS and a Fuzzy Preference Relation. Inf. Sci. 2013, 252, $42-61$. [CrossRef]

49. Lima Junior, F.R.; Osiro, L.; Carpinetti, L.C.R. A Comparison between Fuzzy AHP and Fuzzy TOPSIS Methods to Supplier Selection. Appl. Soft Comput. 2014, 21, 194-209. [CrossRef] 
50. Zhao, H.; Guo, S. Selecting Green Supplier of Thermal Power Equipment by Using a Hybrid MCDM Method for Sustainability. Sustainability 2014, 6, 217-235. [CrossRef]

51. Papadogeorgos, I.; Papapostolou, A.; Karakosta, C.; Doukas, H. Multicriteria assessment of alternative policy scenarios for achieving EU RES target by 2030. In Strategic Innovative Marketing; Kavoura, A., Sakas, D., Tomaras, P., Eds.; Springer Proceedings in Business and Economics; Springer: Cham, Switzerland, 2017.

52. Rani, P.; Mishra, A.R.; Mardani, A.; Cavallaro, F.; Alrasheedi, M.; Alrashidi, A. A Novel Approach to Extended Fuzzy TOPSIS Based on New Divergence Measures for Renewable Energy Sources Selection. J. Clean. Prod. 2020, 257, 120352. [CrossRef]

53. Çolak, M.; Kaya, İ. Prioritization of Renewable Energy Alternatives by Using an Integrated Fuzzy MCDM Model: A Real Case Application for Turkey. Renew. Sustain. Energy Rev. 2017, 80, 840-853. [CrossRef]

54. Karunathilake, H.; Hewage, K.; Mérida, W.; Sadiq, R. Renewable Energy Selection for Net-Zero Energy Communities: Life Cycle Based Decision Making under Uncertainty. Renew. Energy 2019, 130, 558-573. [CrossRef]

55. Ligus, M.; Peternek, P. Determination of Most Suitable Low-Emission Energy Technologies Development in Poland Using Integrated Fuzzy AHP-TOPSIS Method. Energy Procedia 2018, 153, 101-106. [CrossRef]

56. Proctor, T. Strategic Marketing, an Introduction, 1st ed.; Taylor \& Francis Ltd.: London, UK, 2008.

57. Weihrich, H. The TOWS Matrix-A Tool for Situational Analysis. Long Range Plan. 1982, 15, 54-66. [CrossRef]

58. Chen, C.-T. Extensions of the TOPSIS for Group Decision-Making under Fuzzy Environment. Fuzzy Sets Syst. 2000, 114, 1-9. [CrossRef]

59. Chen, S.; Wei, Z. A Rational Consensus Model in Group Decision Making based on Linguistic Assessment Information. In Proceeding of the International Conference on Management and Service Science (MASS), Wuhan, China, 24-26 August 2010.

60. Alptekin, N. Integration of SWOT Analysis and TOPSIS Method in Strategic Decision Making Process. Macrotheme Rev. 2013, 2, 1-8.

61. Saaty, T.L. Decision Making with the Analytic Hierarchy Process. Int. J. Serv. Sci. 2008, 1, 83. [CrossRef]

62. World Future Council. A Roadmap for 100\% Renewable Energy in Morocco; World Future Council: Hamburg, Germany, 2017.

63. Bouhal, T.; Agrouaz, Y.; Kousksou, T.; Allouhi, A.; El Rhafiki, T.; Jamil, A.; Bakkas, M. Technical Feasibility of a Sustainable Concentrated Solar Power in Morocco through an Energy Analysis. Renew. Sustain. Energy Rev. 2018, 81, 1087-1095. [CrossRef]

64. Lotfi, M.; Monteiro, C.; Shafie-khah, M.; Catalao, J.P.S. Evolution of Demand Response: A Historical Analysis of Legislation and Research Trends. In Proceeding of the 2018 Twentieth International Middle East Power Systems Conference (MEPCON), Cairo University, Cairo, Egypt, 18-20 December 2018.

65. Cantoni, R.; Rignall, K. Kingdom of the Sun: A Critical, Multiscalar Analysis of Morocco's Solar Energy Strategy. Energy Res. Soc. Sci. 2019, 51, 20-31. [CrossRef]

66. GIZ. No Étude de l'effet sur l'Emploi d'un Régime D'autoproduction avec Facturation nette D'électricité (Loi 13-09 et loi 58-15) issue D'installations Photovoltaïques Connectées au Réseau de Basse Tension au Maroc; Deutsche Gesellschaft für Internationale Zusammenarbeit (GIZ) GmbH: Eschborn, Germany, 2017.

67. OECD/IEA. Renewables 2018. Available online: www.iea.org/statistics/ (accessed on 12 March 2020).

68. Renewable Energy Solutions for the Mediterranean (RES4MED). Country Profile: Morocco 2018. Available online: https://www.res4med.org/wp-content/uploads/2018/06/Country-profile-Marocco-2.pdf (accessed on 12 March 2020).

69. Moore, S. Evaluating the Energy Security of Electricity Interdependence: Perspectives from Morocco. Energy Res. Soc. Sci. 2017, 24, 21-29. [CrossRef]

70. Nordea. Country Profile Morocco. Available online: https://www.nordeatrade.com/en/explore-new-market/ morocco/investment (accessed on 3 March 2020).

71. IEA. Energy Policies Beyond IEA Countries: Morocco 2019; OECD: Paris, France, 2019; Available online: https://doi.org/10.1787/10f93028-en (accessed on 12 March 2020).

72. Schinke, B.; Klawitter, J. Summary: Country Fact Sheet Morocco, Energy and Development at a Glance, Middle East North Africa Sustainable ELECtricity Trajectories (MENA-SELECT) Project; Germanwatch: Bonnn, Germany, 2016.

73. OECD/IEA. World Energy Balances 2018. Available online: www.iea.org/statistics/ (accessed on 12 March 2020). 
74. Schwerhoff, G.; Sy, M. Financing Renewable Energy in Africa-Key Challenge of the Sustainable Development Goals. Renew. Sustain. Energy Rev. 2017, 75, 393-401. [CrossRef]

75. Warren, B. Renewable Energy Country Attractiveness Index (RECAI). Available online: https://www.ey.com/ en_uk/power-utilities/renewable-energy-country-attractiveness-index (accessed on 12 March 2020).

76. Schinko, T.; Komendantova, N. De-Risking Investment into Concentrated Solar Power in North Africa: Impacts on the Costs of Electricity Generation. Renew. Energy 2016, 92, 262-272. [CrossRef]

77. Royaume du Maroc Ministere de I'lndustrie. Industrial Acceleration Plan 2014-2020. Available online: http://www.mcinet.gov.ma/en/content/industrial-acceleration-plan-2014-2020-0 (accessed on 12 March 2020).

78. Choukri, K.; Naddami, A.; Hayani, S. Renewable Energy in Emergent Countries: Lessons from Energy Transition in Morocco. Energy. Sustain. Soc. 2017, 7, 25. [CrossRef]

79. Schinko, T.; Bohm, S.; Komendantova, N.; Jamea, E.M.; Blohm, M. Morocco's Sustainable Energy Transition and the Role of Financing Costs: A Participatory Electricity System Modeling Approach. Energy. Sustain. Soc. 2019, 9, 1. [CrossRef]

80. Tramblay, Y.; Ruelland, D.; Bouaicha, R.; Servat, E. Projected climate change impacts on water resources in northern Morocco with an ensemble of regional climate models. Hydrology in a Changing World: Environmental and Human Dimensions. In Proceeding of the FRIEND-Water 2014, Montpellier, France, 7-10 October 2014. IAHS Publ. 363.

81. Simonneaux, V.; Cheggour, A.; Deschamps, C.; Mouillot, F.; Cerdan, O.; Le Bissonnais, Y. Land Use and Climate Change Effects on Soil Erosion in a Semi-Arid Mountainous Watershed (High Atlas, Morocco). J. Arid Environ. 2015, 122, 64-75. [CrossRef]

82. Kousksou, T.; Allouhi, A.; Belattar, M.; Jamil, A.; El Rhafiki, T.; Arid, A.; Zeraouli, Y. Renewable Energy Potential and National Policy Directions for Sustainable Development in Morocco. Renew. Sustain. Energy Rev. 2015, 47, 46-57. [CrossRef]

83. The World Bank. Morocco Overview. Available online: https://www.worldbank.org/en/country/morocco/ overview\#2 (accessed on 12 March 2020).

84. Trieb, F.; Hess, D.; Kern, J.; Fichter, T.; Moser, M.; Pfenning, U.; Caldez, N.; de la Rua, C.; Türk, A.; Frieden, D.; et al. WP3:North Africa Case Study Final Report Bringing Europe and Third Countries Closer Together through Renewable Energies (BETTER) Project, European Commission Intelligent Energy for Europe; Contract No: IEE/11/845/SI2.61637; European Commission: Brussels, Belgium, 2015.

85. Davies, M.; Elmatbouly, S.; El-Mazghouny, D.; Schellkens, G.; Ahmad, S. Developing Renewable Energy Projects: A Guide to Achieving Success in the Middle East. Available online: https://www.pwc.com/m1/en/ publications/documents/developing-renewable-energy-projects-egypt.pdf (accessed on 3 April 2020).

86. Rady, Y.Y.; Rocco, M.V.; Serag-Eldin, M.A.; Colombo, E. Modelling for Power Generation Sector in Developing Countries: Case of Egypt. Energy 2018, 165, 198-209. [CrossRef]

87. Elkadeem, M.R.; Wang, S.; Azmy, A.M.; Atiya, E.G.; Ullah, Z.; Sharshir, S.W. A Systematic Decision-Making Approach for Planning and Assessment of Hybrid Renewable Energy-Based Microgrid with Techno-Economic Optimization: A Case Study on an Urban Community in Egypt. Sustain. Cities Soc. 2020, 54, 102013. [CrossRef]

88. Davies, M.; Hodge, B.; Ahmad, S.; Wang, Y. Developing Renewable Energy Projects: A Guide to Achieving Success in the Middle East. Available online: https:/www.pwc.com/m1/en/publications/documents/ eversheds-pwc-developing-renewable-energy-projects.pdf (accessed on 3 April 2020).

89. Bohl, D.K.; Hanna, T.; Scott, A.C.; Moyer, J.D.; Hedden, S.G. Sustainable Development Goals Report: Egypt 2030; Frederick S. Pardee Center for International Futures and United Nations Development Programme: Denver, CO, USA; New York, NY, USA, 2018.

90. IRENA. Renewable Energy Outlook: Egypt, Executive Summary; International Renewable Energy Agency: Abu Dhabi, United Arab Emirate, 2018.

(C) 2020 by the authors. Licensee MDPI, Basel, Switzerland. This article is an open access article distributed under the terms and conditions of the Creative Commons Attribution (CC BY) license (http://creativecommons.org/licenses/by/4.0/). 